Rhode Island College

Digital Commons @ RIC

$12-1-2019$

\title{
The Impact of Intrathecal Dexmedetomidine as an Adjuvant to Bupivacaine on Postoperative Pain
}

Stephanie Wilson

Follow this and additional works at: https://digitalcommons.ric.edu/etd

Part of the Nursing Commons

\section{Recommended Citation}

Wilson, Stephanie, "The Impact of Intrathecal Dexmedetomidine as an Adjuvant to Bupivacaine on Postoperative Pain" (2019). Master's Theses, Dissertations, Graduate Research and Major Papers Overview. 322.

https://digitalcommons.ric.edu/etd/322

This Major Paper is brought to you for free and open access by the Master's Theses, Dissertations, Graduate Research and Major Papers at Digital Commons @ RIC. It has been accepted for inclusion in Master's Theses, Dissertations, Graduate Research and Major Papers Overview by an authorized administrator of Digital Commons @ RIC. For more information, please contact digitalcommons@ric.edu. 



\section{THE IMPACT OF INTRATHECAL DEXMEDETOMIDINE AS AN ADJUVANT TO BUPIVACAINE ON POSTOPERATIVE PAIN}

A Major Paper Presented

by

Stephanie Wilson

Approved:

Committee Chairperson

Committee Members

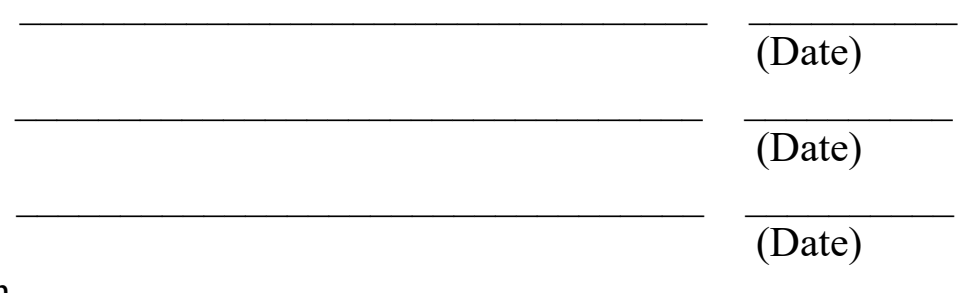

Director of Master's Program (Date)

Dean, School of Nursing 
THE IMPACT OF INTRATHECAL DEXMEDETOMIDINE AS AN ADJUVANT TO BUPIVACAINE ON POSTOPERATIVE PAIN

by

Stephanie Wilson

A Major Paper Submitted in Partial Fulfillment

of the Requirements for the Degree of

Master of Science in Nursing

in

The School of Nursing

Rhode Island College

2019 


\begin{abstract}
Postoperative pain is an unpleasant consequence of all surgical procedures. It is an unpleasant sensory and emotional experience associated with actual or potential tissue damage. There are many negative consequences to postoperative pain including delayed recovery, increased healthcare costs, and overall dissatisfaction with care. There are many methods to minimize postoperative pain. Spinal anesthesia has been used for years to improve postoperative pain across a variety of surgical procedures. New research has shown that the use of adjuvant medications with intrathecal bupivacaine greatly improves postoperative pain. One adjuvant medication is dexmedetomidine. The purpose of this systematic review was to determine if the administration of intrathecal dexmedetomidine, as an adjuvant medication to bupivacaine, impacts postoperative pain in adult patients undergoing surgery. A literature review was conducted using the PRISMA flow diagram. Data was then collected from each study and a cross study analysis was conducted. Findings indicated, in all studies, the addition of dexmedetomidine to intrathecal bupivacaine decreased postoperative pain levels. Integration of dexmedetomidine into spinal anesthesia can make an immense difference in postoperative analgesia and recovery, an important consideration for anesthesia providers.
\end{abstract}




\section{Table of Contents}

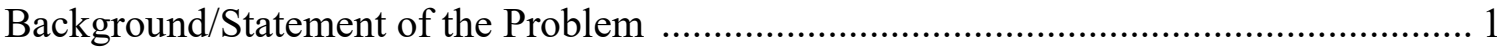

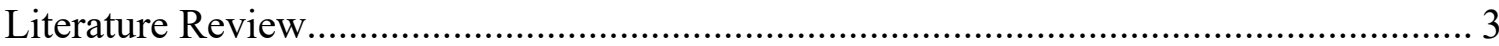

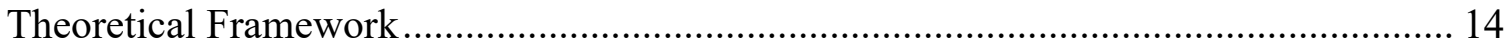

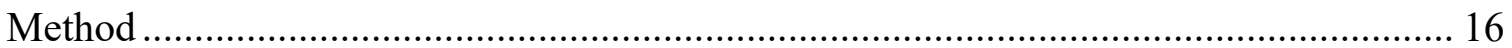

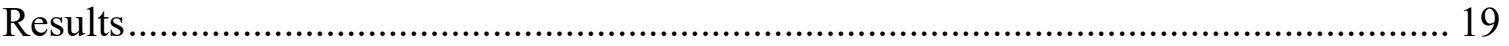

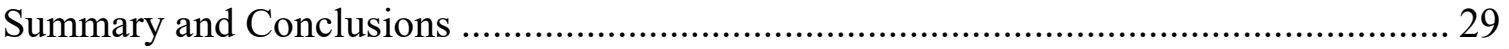

Recommendations and Implications for Advanced Nursing Practice ........................... 32

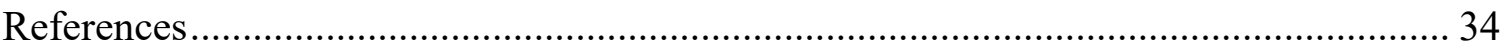

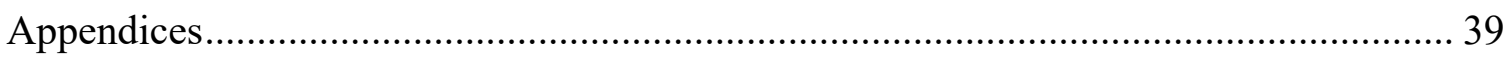


The Impact of Intrathecal Dexmedetomidine as an Adjuvant to Bupivacaine on Postoperative Pain

\section{Background/Statement of the Problem}

Postoperative analgesia is a substantial and current issue in the healthcare field today. Unfortunately, postoperative pain is inadequately managed in greater than $80 \%$ of patients in the United States (U.S.) (Gan, 2017). Patients that undergo surgical procedures can suffer from harsh complications following the procedure. Even when surgery is successful, patients suffer from pain postoperatively.

The number of surgeries being performed is at an all-time high and will continue to increase as advances in medical technology allow surgeons to perform procedures they never have before. Despite improved understanding of pain mechanisms, increased awareness of the prevalence of postsurgical pain, advances in pain-management approaches and inadequately controlled postoperative pain continues to be a problem (Gan, 2017).

Postoperative pain is associated with many negative outcomes, both for the patient and the hospital. The patient will suffer from prolonged recovery, immobility, increased morbidity, and overall dissatisfaction with care (Gan, 2017). Both the patient and the hospital will experience increased medical costs due to increased medication use and a prolonged hospital stay. More importantly, poorly managed acute pain can result in the development of chronic pain (Gan, 2017).

Many interventions are available for treating acute postoperative analgesia but

may fall short of fully eradicating it. A favorable management strategy for postoperative pain is to address it pre-emptively, instead of waiting until the post-operative period. Intra-operatively the anesthesia provider can administer a variety of medications that will 
greatly improve analgesia following surgery. One method is to use local anesthetics and possible adjuvants to local anesthetics, such as dexmedetomidine. Garimella and Cellini (2013) stated that intrathecal administration of a local anesthetic $(0.5 \%$ bupivacaine $)$ at induction of anesthesia results in good postoperative analgesia for up to 24 hours. If an adjuvant medication were to be added to the bupivacaine, that time could be even longer.

The use of adjuvant medications with local anesthetics to help improve postoperative analgesia is a new intervention that is still being researched. Some medications being used as adjuvants are dexamethasone, clonidine, and dexmedetomidine. The benefit of these medications towards postoperative analgesia needs to be considered, along with other effects they might pose. Overall, it is believed the administration of these medications with local anesthetics will improve postoperative analgesia. This is an important consideration for anesthesia providers, as it could make an immense difference in postoperative analgesia and recovery.

Effectively treating pain leads to patient comfort, which allows for fewer complications, early mobility, and early discharge. These positive outcomes not only benefit the patient, but the hospital as well. Fewer complications and early discharge result in decreased health costs for the facility. With thousands of surgeries being performed daily, the need for controlled postoperative analgesia is essential.

Therefore, the purpose of this paper is to complete a systematic review to determine if the administration of intrathecal dexmedetomidine, as an adjuvant medication to bupivacaine, impacts postoperative pain in adult patients undergoing surgery.

Next, the review of literature will be presented. 


\section{Literature Review}

A literature review was conducted using the databases CINAHL, Medline, and PubMed. A combination of search terms were used to gather the appropriate research articles. Those search terms were: adjuvant, postoperative pain, local anesthesia, dexmedetomidine, dexamethasone, and clonidine. The search was limited to peer reviewed articles and written in the English Language. There was no limit entered for year published, but all the articles chosen were published between 2007-2018.

\section{Definition and Pathophysiology of Pain}

The International Association for the Study of Pain (IASP) defines pain as "an unpleasant sensory and emotional experience associated with actual or potential tissue damage, or described in terms of such damage" (Merksey, H., \& Bogduk, N., 2012). There are many different categories of pain, but for this review the focus is on nociceptive pain. When there is damage to tissues, the body transmits a signal to the brain. It does so by a process termed nociception, which is defined as the neural process of encoding and transducing the noxious stimuli received by the body (Dubin \& Patapoutian, 2010). The presence of peripheral sensory neurons throughout the body allows this process to occur. These specialized neurons are called nociceptors.

Nociceptors are found in the skin, bone, muscle, and joints. They are activated by chemicals, such as Substance P or Glutamate, and are released when there is tissue damage. This is the first phase of the pain pathway and is referred to as transduction. The chemicals that are released excite the nociceptors, producing an action potential. Dubin and Patapoutian (2010) defined action potential as an electric signal that is propagated along nerves, enabling communication between neurons within the pain 
pathway. This electric signal travels to the dorsal horn of the spinal cord where it synapses with secondary neurons and then travels to the thalamus within the brain. This is the second phase of the pain pathway and is called transmission. Next, the process of perception allows the body to become conscious of the noxious stimuli and allows modulation of pain to take place. Modulation involves facilitatory and inhibitory pathways in the spinal cord (Dubin \& Patapoutian, 2010). This causes the release of neurotransmitters that aim to inhibit nociception to free the body of pain, completing the pain pathway.

In a descriptive study conducted by Rodriguez (2015), it is stated that pain elicits protective reflexes such as an unconscious withdrawal from the noxious stimulus, muscle spasms, and other autonomic reactions. This response occurs following the perception and modulation of a pain signal. For example, if you were to burn your finger while cooking dinner, the second your finger touched the hot pan nociceptors would respond to the temperature and relay a signal through the neuronal axon up to the spinal cord, and then to the brain causing you to withdraw your hand from the source of pain.

Pain is an ongoing problem that is dominating society. While there are many causes of pain, acute postoperative pain is an evident issue existing in healthcare today. Much research has been conducted on interventions to reduce postoperative pain but postoperative pain is not adequately managed in greater than $80 \%$ of patients in the U.S. (Gan, 2017).

\section{Postoperative Pain}

Management of postoperative pain is essential in the surgical patient. Pain causes discomfort, which leads to many postoperative complications including pneumonia, 
mobility issues, constipation, and prolonged rehabilitation. Pain also increases the stress response of the immune system, causing difficulties with healing (Banks, 2007). There are many interventions used to treat postoperative pain. These interventions are key in facilitating positive patient outcomes following surgical procedures. While there is no defined best method of treating pain, heath care providers must consider that under treatment of postoperative pain results in many negative effects, and it is crucial to be informed of all current interventions to treat postoperative pain (Banks, 2007).

Recent evidence determined that $80 \%$ of patients who underwent surgical procedures experienced acute postoperative pain, and less than half reported adequate pain relief (Chou et al., 2016). This is an astounding statistic that led to the development of new guidelines regarding management of postoperative pain control. In 2016, The American Pain Society published 32 recommendations to promote effective management of postoperative pain (Chou et al). These recommendations range from generalized to specific. Within the new guidelines, the use of local anesthetics is highly recommended. Chou et al. (2016) stated that local anesthetics have been shown to be effective as a component of multi-modal analgesia for management of postoperative pain associated with many surgical procedures; however, prior to treating pain, it must be understood how to measure it.

Measuring Postoperative Pain. Earlier, this review addressed the pathophysiology of pain, including perception of pain. As stated before, it is when the brain interprets and processes a pain signal. This is a subjective phenomenon that can vary between individuals. A surgery that causes considerable pain for one person could cause no pain at all for someone else due to the processing of pain signals in the brain. 
This poses a problem; how do we measure pain if it is perceived differently in each patient? The subjective nature of pain makes its reliable measurement by health professionals a key factor in its successful management (Coll, Ameen, \& Mead, 2004). A thorough nurse assessment coupled with pain measurement scales is the current standard for addressing postoperative pain.

There are a multitude of scales available to assist with measuring postoperative pain. Among the most commonly used are the Visual Analog Scale (VAS) and the Numerical Rating Scale (NRS). It is important to understand how these scales work to adequately interpret research results regarding postoperative pain. While both scales focus on the patient's perception of pain, they do so in different manners.

The VAS consists of a 100-millimeter line, usually horizontal, with the ends of the lines representing extremes of pain interpretation. The left side represents 'no pain' and the opposite end represents 'unbearable pain' (Coll et al., 2004). The patient is asked to point or make a mark on the line where their pain level falls. That point is then measured how far away from the left (lower) side of the line it is in millimeters. The larger the distance the more intense the pain. Once the distance is determined, the pain can be treated appropriately.

The NRS measures pain similarly. Its original form consisted of a horizontal line, in which one end is labeled 0 and the other end labeled 10; the patient is asked to pick a point along the line, from 0-10, to identify the intensity of their pain (Coll et al., 2004). Since its original development different versions of this scale have been produced but the generality of rating pain from $0-10$ is one of the most commonly used approaches today (Coll et al., 2004). 
Validity of the VAS and NRS. Valid and reliable pain assessment tools are essential in the management and treatment of postoperative pain. Medical professionals use pain scales to guide treatment plans. If the scales are unreliable, the treatment plan will be inadequate. Studies have been conducted to assess validity and reliability of the different pain scales. A systematic review by Hjermstad et al. (2011) examined the use and performance of unidimensional pain scales, including the VAS and the NRS, in cancer patients. Hjermstad et al. (2011) found that both the VAS and NRS work well, and the most important choice is not the type of scale, but the conditions related to its use. It is necessary to choose the scale based on the patient's level of cognitive functioning. Although the VAS was the most frequently used pain scale, it was found that the NRS suited some patients better. For example, Hjermstad et al. (2011) reported that the NRS was superior in 11 studies due to ease of use and high compliance, while lower compliance was found with the VAS in patients associated with higher age, degree of trauma, or other impairments. Thus, it can be assumed the scale is better utilized when patient specific factors are considered, but the subjectivity of pain makes it necessary to assess pain perception in a standardized fashion. Hjermstad et al. (2011) found that both the NRS and the VAS work well in comparison, so either tool is acceptable.

Once a measurement technique is determined, the provider can determine what the best plan for treatment is. There are many approaches to treating postoperative pain, but this review will focus on local anesthetics.

\section{Local Anesthetics and Their Role in Pain Control}

Local anesthetics contain a group of medications that work by inhibiting sensory, motor, and autonomic nerve function (Butterworth, Mackey, \& Wasnick, 2013). These 
are medications classified as esters or amides that block nerve function, using the nerve roots as the site of action. Normally, activation of sodium channels causes an influx of sodium ions, generating an action potential (Butterworth et al., 2013). Local anesthetics diffuse into the cell where they bind to sodium channels, blocking them. This prevents depolarization, which inhibits any action potentials from being spread. By preventing the action potential, sensation in that area is decreased or completely hindered. Local anesthetics are commonly used alone in surgical procedures but can be combined with other medications to improve analgesic outcomes. The main local anesthetics used in practice today are bupivacaine, ropivacaine, levobupivacaine, and hyperbaric bupivacaine.

Bupivacaine. Bupivacaine is the preferred local anesthetic in caudal, epidural, and spinal anesthesia and is used to manage acute and chronic pain (Paganelli \& Popescu, 2015). In addition to blocking sodium channels intracellularly, bupivacaine has been thought to have inhibitory effects on the N-Methyl-D-aspartic acid (NMDA) receptor. Inhibition of the NMDA receptor is an effective strategy in prevention and management of chronic pain syndromes (Paganelli \& Popescu, 2015).

Bupivacaine is considered a long acting local anesthetic with a duration time of four to eight hours (Paganelli \& Popescu, 2015). Bupivacaine is also known for its high level of sensory anesthesia and can be administered locally in the skin or regionally into the spine, which is referred to as intrathecal administration. Intrathecal administration consists of injecting the medication directly into the spinal column and into the cerebrospinal fluid. Injecting the medication into the spine allows for regional anesthesia, which blocks sensation in an area of the body. 


\section{Adjuvants to Local Anesthetics to Improve Postoperative Pain}

The use of adjuvants with local anesthetics has been practiced for several years now but continues to be a relevant subject of interest (Wiles \& Nathanson, 2010). While local anesthetics have satisfactory effects, there continues to be an ongoing search for medications with longer duration of action, better nerve selectivity, less degree of motor block, and a lower occurrence of systemic toxicity (Wiles \& Nathanson, 2010). The use of adjuvant medications along with local anesthetics aims to provide these outcomes. With the ability to prolong local anesthetic blockade, specifically sensory block, there would be a drastic decrease in postoperative pain levels. There are several medications that have been trialed for adjuvants to local anesthetics including clonidine and dexamethasone. These medications will be discussed briefly in this literature review, but the focus is on dexmedetomidine as an adjuvant and will be discussed in more depth.

Clonidine as an adjuvant to local anesthetic. Clonidine is a selective 2 adrenergic agonist and works by decreasing peripheral vascular resistance. As a result blood vessels relax, allowing decreased blood pressure and heart rate. A prospective, randomized, controlled trial (RCT) by Chakraborty, Chakrabarti, Mandal, Hazra, and Das (2010), compared the effect of low dose clonidine versus placebo as an adjuvant to bupivacaine. Quantitative data was collected through an experimental, double blinded study approach. The sample included 70 participants, ages 18-60, and participants were randomly allocated into one of two groups. Group A received bupivacaine with clonidine, while Group B received bupivacaine with normal saline. Chakraborty et al. (2010) found a significant difference of approximately 221 minutes from the time group A needed analgesia medication to the time Group B needed to be medicated $(p<0.001)$. 
This study suggested that low dose clonidine as an adjuvant to bupivacaine prolonged the duration of analgesia.

Gorniak, Proost, Veckeneer, Mulder, and Wubbels, (2014) conducted a prospective RCT, which aimed to determine the effect of clonidine as an adjuvant to levobupivacaine on postoperative analgesia. The study included 120 participants randomly assigned to two groups. Group one received only levobupivacaine while group two received levobupivacaine with clonidine. Data was collected by a patient selfreported questionnaire, and only 101 participants completed and returned the questionnaire. The participants were asked to rate post-operative pain using the VAS ranging from 0-10, and 10 being the worst pain imaginable (Gorniak et al., 2014). Gorniak et al. (2014) found that the use of clonidine as an adjuvant to local anesthesia is limited in terms of benefits and reducing post-op pain. Participants who reported pain compared to those who did not report pain in the control group were 18:34, and 18:31 in the clonidine group. Hence, there was not a significant difference between the two groups.

Dexamethasone as an adjuvant to local anesthetics. Dexamethasone is a corticosteroid; a class of medications that aid primarily in reducing inflammation. Desmet et al. (2013) conducted a prospective, randomized, placebo-controlled study in which researchers hypothesized that intravenous (IV) and perineural (around nerves) dexamethasone have an equal effect of prolonging analgesia when used with the local anesthetic nerve block ropivacaine. A sample size of 150 participants was allocated randomly into one of three groups. Group one received ropivacaine only, group two received ropivacaine with perineural dexamethasone $10 \mathrm{mg}$, and group three received IV 
dexamethasone $10 \mathrm{mg}$ only. Data was collected by the NRS, on a scale of 0-4 with 4 being severe pain. Researchers found dexamethasone significantly prolonged the duration of analgesia $(p<0.001)$. The results strongly supported the researcher's hypothesis.

Desmet et al. (2015) conducted a second RCT in which dexamethasone was combined with a local anesthetic for shoulder surgery. The researchers hypothesized that different doses of dexamethasone would prolong analgesic duration of the local anesthetic block. The study was a prospective, placebo-controlled, randomized trial that allocated 240 participants into four separate groups, 60 in each group. Participants either received IV saline $0.9 \%$, or a dose of dexamethasone $1.25 \mathrm{mg}, 2.5 \mathrm{mg}$, or $10 \mathrm{mg}$ during surgery. All were adjuvants to the local anesthetic ropivacaine. Data was collected by patient self-report, and participants would rate their pain as none, mild, moderate, or severe. Researchers found that IV dexamethasone prolongs the duration of postoperative analgesia with a greater effect at a dose of $10 \mathrm{mg}$ than $2.5 \mathrm{mg}$ (Desmet et al., 2015). No statistical difference was noted between dexamethasone doses of $2.5 \mathrm{mg}$ versus $10 \mathrm{mg}$. Generally, when dexamethasone was used with ropivacaine analgesia was prolonged, as opposed to when ropivacaine was used with normal saline. The results supported the researcher's hypothesis.

Dexmedetomidine as an Adjuvant to Local Anesthetics. Dexmedetomidine is a selective alpha- 2 agonist approved for sedation but has more recently been investigated for its analgesic effects. It has an effect on the body both peripherally and centrally. Peripherally, it decreases the release of norepinephrine causing inhibition of nerve action potentials (Nazir \& Jain, 2016). Centrally, it causes inhibition of the release of substance 
$\mathrm{P}$ at the level of the dorsal root neuron resulting in analgesia (Nazir \& Jain, 2016). More specifically, it has been used intrathecally as an adjuvant to spinal anesthesia to assist in prolonging efficacy of both medications (Das et al., 2015).

Das et al. (2015) conducted a prospective, double blind, randomized controlled study and compared two different doses of dexmedetomidine added to bupivacaine on duration of analgesia. The sample consisted of 100 participants scheduled to have an abdominal hysterectomy under spinal anesthesia. The participants were allocated using a computer-generated random number list into two different groups. Participants either received $5 \mathrm{mcg}$ or $10 \mathrm{mcg}$ of dexmedetomidine. Both doses of dexmedetomidine were administered along with $15 \mathrm{mg}$ of bupivacaine. The anesthetic technique was standardized for each participant, and the intervention was applied exactly as stated, assuring intervention fidelity. Data was collected postoperatively by patients' self-report of pain based on the VAS. After analyzing the data, researchers found that spinal dexmedetomidine increased the time before first analgesic use was required, and it also decreased analgesic consumption. The group that received the $10 \mathrm{mcg}$ waited longer before taking the first dose of analgesic medications than the group that received only $5 \mathrm{mcg}(\mathrm{P}<0.05)$, and also required less breakthrough pain medication overall (Das et al., 2015). The evidence supported the author's hypothesis.

A study was conducted by Nazir and Jain (2016) that aimed to compare the postoperative analgesic effects of dexmedetomidine for brachial plexus blockade along with bupivacaine. A brachial plexus blockade is when a local anesthetic is injected during surgery on the upper extremity. This was a prospective, randomized, controlled trial that consisted of 70 participants. Participants were allocated into two separate 
groups. Participants in the control group received bupivacaine with normal saline and participants in the experimental group received bupivacaine with dexmedetomidine. Data was collected postoperatively by patients' self-report of pain using a NRS of 1-10, 10 being the worst pain. At a score of 4, rescue analgesic was administered. The researchers assessed how long it took for the first dose of rescue analgesic to be administered. After analyzing the data researchers found the time to first analgesia was significantly prolonged in the experimental compared to the control group $(p<0.0001)$. Nazir and Jain (2016) concluded that dexmedetomidine is an effective adjuvant to bupivacaine.

Next, the theoretical framework utilized for this systematic review will be presented. 


\section{Theoretical Framework}

The Preferred Reporting Items for Systematic Reviews and Meta-Analyses (PRISMA) statement was designed to assist in the quality of reporting of controlled trials. A systematic review is an analysis of a relevant research question that uses systematic methods to identify, select, and appraise relevant research (Moher, Liberati, Tetzlaff, Altman, \& PRISMA Group, 2009). In a meta-analysis, statistical data is used to analyze and summarize the results. Systematic reviews and meta-analyses serve a significant purpose in healthcare. The results of various studies can be reviewed and summarized so relevant information can be extracted and reported. Writing a systematic review can be a complex and challenging task, therefore the PRISMA statement was developed to assist and improve the process of reporting.

The PRISMA statement evolved from the Quality of Reporting of Meta-analyses (QUOROM) statement in 2005. QUOROM is a guideline for appraising meta-analyses. The goal of expansions was to include systematic reviews as well. The PRISMA statement consists of a 27 -item checklist and a flow diagram with four phases (Moher et al., 2009). The PRISMA checklist (Appendix A) guides you through a series of steps to assist with evaluation of a study. The steps are grouped into seven sections: title, abstract, introduction, methods, results, discussion, and funding. Each section is further divided into topics. This checklist will be utilized by the author to assure completeness of the systematic review.

The PRISMA statement also contains a flow diagram (Appendix B) that is a model used for depicting phases of a systematic review. It depicts the stages of identification, screening, eligibility, and studies included. 
All research is valuable to clinical practice and the importance of that research relies on what was done, what was found, and the clarity of information (Moher et al., 2009). The PRISMA statement was utilized by the author during production of the systematic review.

The CASP checklist (Appendix C) was also utilized to critically appraise the data. This tool proposes a systematic process to assist with identifying strengths and weaknesses of a research study (Singh, 2013). The CASP tool has several checklists, each for a specific type of research study. The checklist designed for a systematic review was utilized for this paper and will be described further in the methods section.

The methods of this systematic review will be discussed next. 


\section{Methods}

\section{Purpose}

The purpose of this paper is to complete a systematic review to determine if the administration of intrathecal dexmedetomidine, as an adjuvant medication to bupivacaine, impacts postoperative pain in adult patients undergoing surgery.

The research question to be examined in this review is: Does the administration of intrathecal dexmedetomidine, as an adjuvant medication to bupivacaine, decrease time to first analgesia, in postoperative adult patients?

\section{Inclusion and Exclusion Criteria}

Inclusion criteria consisted of randomized controlled trials published in the last ten years, written in the English language, participants 18 years or older and undergoing a surgical procedure in which dexmedetomidine was used as an adjunctive to intrathecal bupivacaine. Exclusion criteria included participants younger than 18 years old, articles that used adjuvant medications other than dexmedetomidine, and articles that used local anesthetics other than intrathecal bupivacaine.

\section{Search Strategy}

The PRISMA checklist and flow diagram were used to guide the search strategy. Research was collected using the databases CINAHL, Medline, and PubMed. The search terms used were: dexmedetomidine, postoperative pain, and intrathecal bupivacaine. The articles were screened for inclusion and exclusion criteria. Studies were chosen based on the title, the abstract and whether it correlated with the purpose of this paper which was to complete a systematic review to determine if the administration of intrathecal 
dexmedetomidine, as an adjuvant medication to bupivacaine, impacts postoperative pain in adult patients undergoing surgery.

\section{Data Collection and Synthesis}

Each article was carefully read and pertinent information was extracted. Data was entered into two tables created by the author of this systematic review. The data tables summarize information that is easily interpretable. Data collected and displayed in Table 1 include purpose, setting, sample size, and design method. Data collected and displayed in Table 2 include procedure, pain scale used, results, and limitations of the study. Table 1.

Data Collection Tool 1

\begin{tabular}{|l|l|l|l|}
\hline Purpose & Setting & Sample & Design Method \\
& & & \\
\hline
\end{tabular}

Table 2.

Data Collection Tool 2

\begin{tabular}{|l|l|l|l|}
\hline Procedure & Pain Scale Used & Results & Limitations \\
\hline
\end{tabular}

\section{Critical Appraisal Tool}

The CASP checklist was used to guide the critical appraisal of selected articles. It consists of three sections, totaling eleven questions that are used to guide the review process.

Section A asks if the results are valid. This section starts with two questions that are referred to as screening questions, which can be answered quickly and easily but must be addressed before moving on. Once it is determined the results are valid, the next 
section addresses what the results are. Section B asks two questions: What are the overall results of the review, and the second asks how precise the results are. Lastly, Section C addresses whether the results will be helpful locally and whether the results are feasible. Prompts are given throughout the three sections to facilitate answering the questions.

The CASP tool was used to systematically evaluate each article and its results. The guidelines are clear and concise, making it easy to understand. The questions are wide ranging and offer direction, facilitating a structured approach to analyzing evidence (Singh, 2013).

\section{Cross Analysis}

A cross study analysis was performed that compared the effects of dexmedetomidine to the time of first analgesic request postoperatively as well as type of procedure, pain measurement tool, and dosage of medications used in each study. A table was formulated to compare the results of the control group compared to the intervention group across studies (Table 3). The similarities and differences between the studies will be compared.

Table 3.

Cross Study Analysis

\begin{tabular}{|l|l|l|l|l|l|}
\hline Authors & $\begin{array}{l}\text { Procedure/Type } \\
\text { of surgery }\end{array}$ & $\begin{array}{l}\text { Pain } \\
\text { Measurement } \\
\text { Tool }\end{array}$ & $\begin{array}{l}\text { Dosage } \\
\text { Used }\end{array}$ & $\begin{array}{l}\text { Control } \\
\text { Group- } \\
\text { mean time } \\
\text { to first } \\
\text { analgesic } \\
\text { request } \\
\text { (minutes) }\end{array}$ & $\begin{array}{l}\text { Intervention } \\
\text { Group- mean } \\
\text { time to first } \\
\text { analgesic } \\
\text { request } \\
\text { (minutes) }\end{array}$ \\
& & & & \\
\hline
\end{tabular}

Next, the results will be discussed. 


\section{Results}

\section{Data Collection}

The PRISMA flow diagram was utilized to guide the search for pertinent literature. Multiple databases were used to identify pertinent records, and duplicates were excluded. An initial broad search was performed using the term "dexmedetomidine". Search results showed 1,287 results through CINAHL, 4,214 through PubMed, and 4,510 through Medline. The search was then narrowed by applying the secondary term “postoperative pain”. Results from CINAHL, PubMed, and Medline dropped to 165, 233, and 549 respectively. The search was narrowed once more by adding the term “bupivacaine”. CINAHL, PubMed, and Medline results dropped further to 27, 36, and 75 respectively. The records were then screened for availability of full text, and further screened for inclusion and exclusion criteria. After eligibility of articles was determined, the number of RCTs were totaled and accounted for. Six RCTs were chosen for review (Figure 1). 


\section{PRISMA 2009 Flow Diagram}
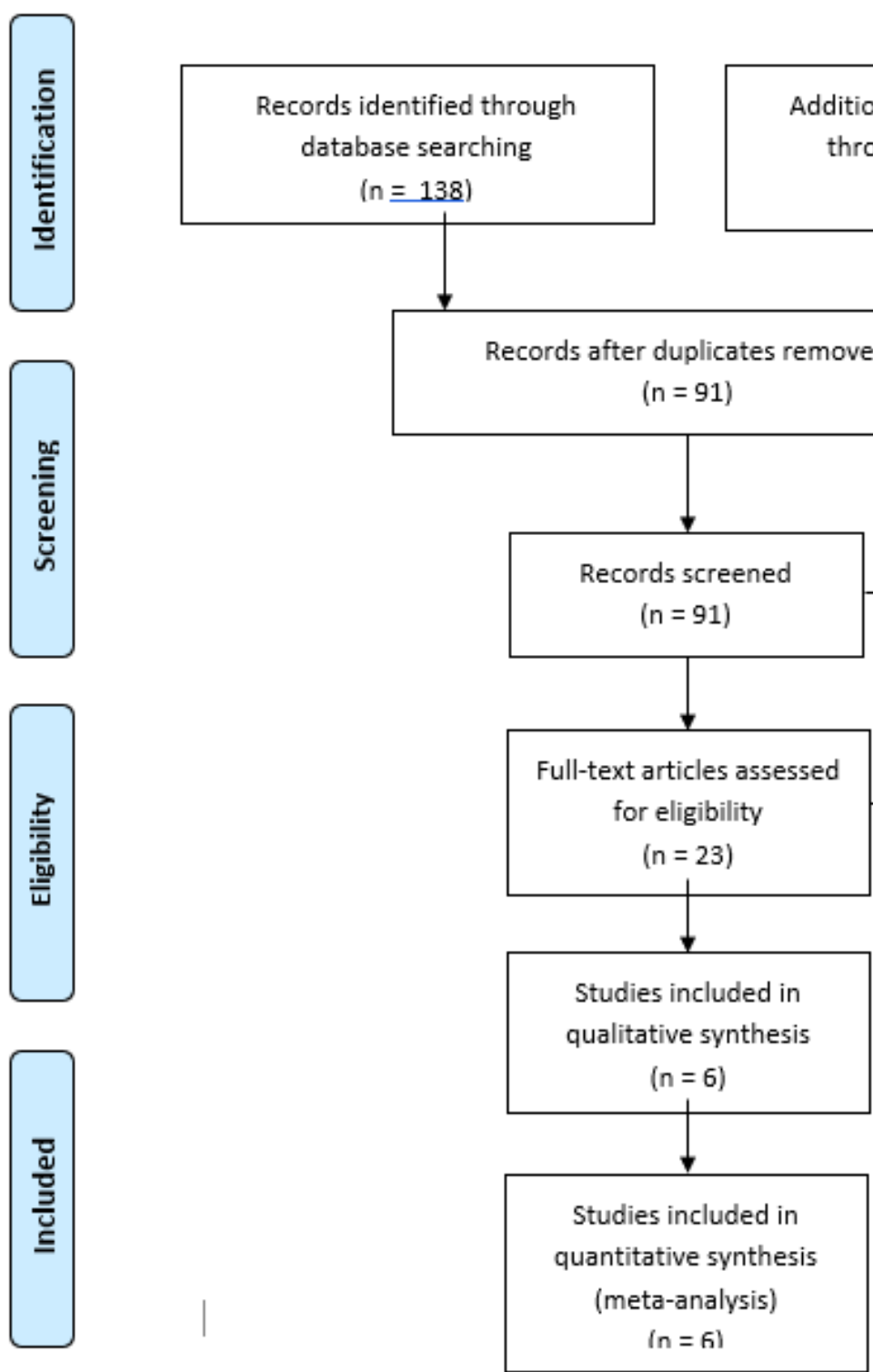

Figure 1. PRISMA Flow Diagram 
An RCT by Kim, Kim, Lee, and Kil (2013) assessed 54 elderly patients undergoing transurethral resection of the prostate (TURP) under a spinal anesthetic using low dose bupivacaine. The authors calculated a sample size of 23 patients in each group would be required to achieve power of $80 \%$ and a significance level of 0.05 . A random allocation sequence was used to assign groups: the experimental group received spinal dexmedetomidine in addition to bupivacaine and the control received only bupivacaine. A spinal puncture was performed with the patient in the lateral decubitus position at the $3^{\text {rd }}-4^{\text {th }}$ or $4^{\text {th }}-5^{\text {th }}$ interbody lumbar space with a midline approach using a 25 -gauge Quincke needle. After confirmation of CSF flow the pre-prepared drug was administered and the patient was placed in the supine position. Those in the experimental group received 3 micrograms $(\mathrm{mcg})$ of dexmedetomidine combined with 6 milligrams $(\mathrm{mg})$ of hyperbaric bupivacaine, while the control group received $6 \mathrm{mg}$ of bupivacaine with 3 mcg of saline. Following the procedure, the patient was brought to the post-anesthesia recovery unit (PACU) where the time until first analgesic request was recorded. Pain levels were assessed using the VAS at 30 minutes post-operatively, and again at 6 hours, 24 hours, and 36 hours after discharge. The authors found the number of patients requiring postoperative analgesics was similar between the two groups, but the dexmedetomidine group had fewer overall requirements for rescue analgesic medications with a $\mathrm{p}$ value $<0.01$. The mean time to first analgesic request in the control group was 345 minutes, compared to the experimental group, which was 1360 minutes. Kim et al. (2013) also reported that time to first analgesic was longer in the dexmedetomidine group, $p=0.039$ (Appendix D). 
Abdelhamid and El-lakany (2013) assessed 62 patients presenting for inguinal hernia repair over a three-month period. Patients were ages 18-60 years old. Patients were randomized into one of two groups using the sealed envelope technique. One group received $3.5 \mathrm{ml}$ of bupivacaine with $5 \mathrm{mcg}$ of dexmedetomidine, and the other group received $3.5 \mathrm{ml}$ of bupivacaine with normal saline. A 25-gauge pencil point needle was inserted through the $4^{\text {th }}-5^{\text {th }}$ interbody lumbar space and medication was injected over 10 seconds. Postoperatively, the amount of time until first analgesic request was recorded. Total analgesic consumption over 24 hours was also recorded. No pain scale was used. The authors found that analgesic requirements were significantly lower in the group that received the bupivacaine and dexmedetomidine and reported a $p$ value of $<0.0001$. Total analgesic consumption was also lower in the group that received bupivacaine with normal saline ( $p$ value of $<0.0001)$. The mean time until first analgesic request was 259 minutes in the group that did not receive dexmedetomidine, compared to 381 minutes in the group that did receive the dexmedetomidine (Appendix E).

Bi, Cui, Zhang, Song, and Zhang (2017) assessed 60 patients presenting for elective cesarean section undergoing spinal anesthesia. Patients were of ASA status 1 or 2, ages ranged from 18-40. Patients were randomized into one of three groups using a computer-generated randomization table. One group received $10 \mathrm{mg}$ of bupivacaine alone, the second group received $10 \mathrm{mg}$ of bupivacaine with $3 \mathrm{mcg}$ of dexmedetomidine, and the third group received $10 \mathrm{mg}$ of bupivacaine with $5 \mathrm{mcg}$ of dexmedetomidine. Lumbar epidural anesthesia was induced using a 25 -gauge pencil point needle. The drugs were injected at a rate of $1 \mathrm{ml} / 15$ seconds, and each spinal was administered by the same anesthesiologist. Postoperative pain was assessed using the VAS at 6 and 12 hours after 
surgery. The time to first rescue analgesic was also recorded. The authors found that pain ratings at 6 hours were higher in the group that received bupivacaine alone ( $p$ value $=0.0032)$. There was no difference between the groups at 12 hours $(p=0.3533)$.

Additionally, the time to first rescue analgesic was not significantly different ( $p=0.7096$ ). The mean time to first request for analgesia was 1320 minutes in the group that received no dexmedetomidine, compared to 1488 minutes and 1428 minutes in the groups that received $3 \mathrm{mcg}$ and $5 \mathrm{mcg}$ of dexmedetomidine respectively (Appendix G).

Patro, Deshmukh, Ramani, and Das (2016) conducted a study of 60 patients undergoing infra-umbilical surgery with spinal anesthesia. The types of infra-umbilical surgeries included in the study were hysterectomies, hernia repairs, appendectomies, and open urosurgical procedures. Participants were ages 18-45 and ASA status 1 or 2. Data was collected over a two-month period. The participants were randomly allocated into two groups using the sealed envelope technique. Group one received $3 \mathrm{ml}$ of $0.5 \%$ hyperbaric bupivacaine with $0.5 \mathrm{ml}$ of normal saline. Group two received $3 \mathrm{ml}$ of $0.5 \%$ hyperbaric bupivacaine with $5 \mathrm{mcg}$ of dexmedetomidine. The medication was prepared by an anesthesiologist not involved in the study. Lumbar puncture was performed with the patient in left lateral decubitus position with a 25-gauge needle inserted at the L3-L4 intervertebral space. VAS was recorded postoperatively at three, six, and twelve hours. Rescue analgesics were administered when VAS was greater than three. The cutoff point for the study was when the patient required the first dose of rescue analgesia. The authors found a significant difference in duration of analgesia between the two groups. After three hours, the mean VAS in group one was 1.03 and 0.03 in group two. At six hours, the mean VAS in group two was 2.67 and 3.7 in group one $(p<0.001)$. The mean 
time until first analgesic request postoperatively was 269 minutes in group one and 399 minutes in group two.

Salem, Darweesh, Wanis, and Mohamed (2015) assessed 52 patients undergoing posterolateral lumbar spinal fusion with intrathecal anesthesia. Participants were ages 40-65 years old and ASA status 1 or 2. Participants were separated into one of two groups using the sequentially numbered closed envelopes. Group one received $15 \mathrm{mg}$ of hyperbaric bupivacaine with $5 \mathrm{mcg}$ of dexmedetomidine. Group two received $15 \mathrm{mg}$ of hyperbaric bupivacaine with $0.5 \mathrm{ml}$ of saline. Lumbar puncture was performed in sitting position at the level of L3-L4 intervertebral disc space. A 25-gauge needle was used, and the same anesthesiologist performed all spinals. Also, the same surgeon performed all surgeries. Postoperatively, the total dose of analgesic medication over 24 hours was recorded. The authors found that time to first analgesic request was significantly longer in group one $(p<0.0001)$. Salem et al. (2015) also found the total dose of analgesic medication over 24 hours was smaller in group one $(p<0.0001)$. The mean time until first analgesic request was 399 minutes in group one, compared to 269 minutes in group two (Appendix H).

Yetkas and Belli (2014) assessed 60 male patients undergoing inguinal surgery under spinal anesthesia. Participants were between the ages of 20-30 years old. Patients were divided randomly into three groups. Group one received $15 \mathrm{mg}$ of hyperbaric bupivacaine with $0.5 \mathrm{ml}$ of normal saline; group two received $15 \mathrm{mg}$ of hyperbaric bupivacaine with $2 \mathrm{mcg}$ of dexmedetomidine; and group 3 received $15 \mathrm{mg}$ of hyperbaric bupivacaine with $4 \mathrm{mcg}$ of dexmedetomidine. Lumbar puncture was performed with the patient in a sitting position. A 25-gauge spinal needle was inserted into the L4-L5 disc 
space, and when CSF flow was observed the pre-prepared medical solution was injected. Postoperatively the time until onset of pain was recorded, as well as the total amount of analgesic medication administered over 24 hours. The authors found that time until initiation of pain was significantly longer in group three than in groups one and two ( $p<$ 0.001). They also found that analgesic medication consumption over 24 hours was significantly higher in group one than in groups two and three $(p<0.001)$. The mean time until first analgesic request was 220 minutes in group one, 371 minutes in group two, and 1042 minutes in group three (Appendix F).

\section{Critical Appraisal}

The six randomized control trials discussed in this paper were critically appraised using CASP.

In the study by Kim et al. (2013) a total of 54 elderly patients were randomized into one of two groups to evaluate the adjuvant effects of intrathecal dexmedetomidine with bupivacaine on postoperative pain. All the critical analysis questions were scored "yes" except one question that asked if groups were similar at the start of the trial.

Patients underwent the same surgery and 39 out of 54 participants had more than one systemic disease, but these systemic diseases were not further distinguished between the two groups. It was unclear if the two groups were similar at the start of the study. The patients, healthcare workers, and study personnel were all blinded to the treatment. All participants were treated equally throughout the study (Appendix J).

In the Abdelhamid and El-lakany (2013) study, all participants were randomly divided into two groups using the sealed envelope technique. Most critical appraisal questions were answered "yes" except for two. One asked if groups were similar at the 
start of the trial. Participant ages varied significantly, between 22-56 years old, and the distribution between groups was unclear. Second, all clinically important outcomes were not considered. Immediate outcomes were considered, but nothing beyond the immediate post-operative period was assessed. There was no documented follow up with any of the participants. Participants, healthcare workers, and study personnel were all blinded to the treatment. Groups were treated equally throughout the study (Appendix K).

In the study by Bi et al. (2017) all critical appraisal questions were scored "yes" except for one that asked if all the participants who entered the trial were accounted for at its conclusion. During the study if spinal anesthesia failed, participants would be excluded. The authors did not identify how many spinals failed, and they did not specify how many participants finished the study. All personnel involved with the study were blinded and the groups were treated equally. All clinically important outcomes were considered (Appendix L).

In the study by Patro et al. (2016) all critical appraisal questions were scored "yes". Participants, healthcare workers, and study personnel were blinded to the treatment. Both groups were treated equally, and all important clinical outcomes were considered (Appendix M).

In Salem et al.'s (2015) study, a total of 52 participants were randomized and enrolled into one of the two groups. All personnel involved with the study were blinded to the treatment. Groups were similar at the start of the study. Although, it was unclear if the groups were treated equally; no information was provided by the authors. All clinically important outcomes were considered and no adverse outcomes were noted in the intervention group (Appendix N). 
In the study by Yetkas and Belli (2014), a total of 60 participants were randomized and enrolled into one of the three groups. All critical appraisal questions were scored "yes" except for one that asked if the benefits were worth the harm and cost. This study found clear benefits of using dexmedetomidine with hyperbaric bupivacaine intrathecally with no additional harm to the patient; however, no cost analysis was addressed. All participants, healthcare workers, and study personnel were blinded to the treatment. Groups were similar at the start and treated equally throughout the study (Appendix O).

\section{Cross Analysis}

The randomized control trials of this systematic review were analyzed across studies (Appendix P). The cross analysis compared the effects of dexmedetomidine to the time of first analgesic request postoperatively as well as dose of dexmedetomidine used, type of surgery, and pain scale used.

All randomized control trials included in this systematic review investigated different surgeries. The anesthesia provided for the surgery was the same (spinal anesthesia) but surgical procedures varied. Kim et al. (2013) investigated patients undergoing transurethral prostatectomy; Abdelhamid and El-lakany (2013) investigated lower abdominal surgeries; Yektas and Belli (2014) investigated inguinal surgeries; Bi et al. (2017) investigated cesarean section; Salem et al. (2015) investigated posterolateral lumbar spinal surgeries and; Patro et al. (2016) investigated infraumbilical surgeries. All studies reported improved postoperative pain in the intervention groups. Even though the surgeries being performed were different in each study, the results supported the hypothesis that intrathecal dexmedetomidine would improve postoperative pain. 
Another aspect of each study that was analyzed was the type of pain scale used. Three of the randomized control trials used the VAS, one used the numerical rating scale, and two used no scale at all, instead measuring time in minutes to first analgesic request. As stated earlier, these different methods of evaluating pain are all reliable. Results were similar across all studies, regardless of the type of scale used.

Another aspect compared across studies was time to first analgesic request in the control group versus intervention group. All the randomized control trials in this systematic review reported improved postoperative pain when dexmedetomidine was added to intrathecal bupivacaine. This was shown clearly in the cross-analysis table, represented by longer mean time until first analgesic request. The longer it took for patients to request pain medication in the postoperative period, the longer intrathecal pain relief lasted. The most significant results were found in the study by Kim et. al (2013). Mean time to first analgesic request in the control group was 345 minutes, and in the intervention group it was 1360 minutes. These results showed a significant difference between the two groups $(\mathrm{p}=0.006)$.

The last aspect compared across studies was the dosage of dexmedetomidine used. The dosages of dexmedetomidine across studies ranged from 2-5 mcg. All doses were associated with decreased postoperative pain, but the study by Kim et al. (2013) had the most significant results. This trial used a dose of $3 \mathrm{mcg}$ of dexmedetomidine. This was not the highest dose used, yet it yielded the most significant results. This proposes that even lower dosages of the medication can have profound effects in decreasing postoperative pain levels and a higher dose may not be necessary.

Next, the summary and conclusions section will be presented. 


\section{Summary and Conclusions}

Postoperative pain continues to be a substantial issue in the healthcare field. As stated earlier, it is inadequately managed in the majority of patients. Postoperative pain directly correlates with negative patient outcomes and increased hospital costs. Traditional management of postoperative pain consists of parenteral opioids, which are associated with numerous adverse side effects (Banks, 2007). The nurse anesthetist should utilize all modalities of pain relief throughout surgery to improve postoperative pain. One method is to use local anesthetics and adjuvants to local anesthetics, such as dexmedetomidine.

Local anesthetics may be used in a variety of clinical settings for treating mild to severe pain (Banks, 2007). Furthermore, the addition of dexmedetomidine to local anesthetics can make an immense difference in postoperative analgesia and recovery. The purpose of this paper was to complete a systematic review to determine if the administration of intrathecal dexmedetomidine, as an adjuvant medication to bupivacaine, impacts postoperative pain in adult patients undergoing surgery.

A literature review was conducted utilizing inclusion and exclusion criteria generated by the author. The databases CINAHL, Medline, and PubMed were utilized for the search. The PRISMA flowchart was used to guide the search strategy. A total of six randomized control trials were selected for inclusion. Each article was carefully read and pertinent information was extracted. Data collection tables were formulated for all articles. Information collected from each article included purpose, setting, sample, design method, procedure, pain scale used, results, and limitations. Following data collection, a critical appraisal was performed on the selected articles. The CASP 
checklist was used to guide the critical appraisal. Analysis across studies focused on the type of surgery, the pain scale used, and mean time to first analgesic request for control and intervention group.

All six randomized control trials in this systematic review reported improved postoperative pain when dexmedetomidine was added to intrathecal bupivacaine. Overall analgesia requirements were lower in all intervention groups. The most significant results were found in the study by Kim et al (2013). These results showed a significant difference between the two groups $(p=0.006)$. Time to the first requirement of analgesia was significantly longer in the intervention group.

After thorough evaluation of the literature, limitations to this systematic review were identified. The primary limitation to this systematic review was that each control trial evaluated different surgical techniques. The argument could be made that variations in surgical procedures have different expectations for postoperative pain, therefore the results may not be generalized across procedures. While the results were the same for each trial, a stronger correlation could have been made if the surgical procedures were the same across all studies. Another limitation was the fact that different doses of dexmedetomidine were used in several of the RCTs. The use of dexmedetomidine showed improved postoperative pain, but the ideal does needs to be further investigated. In addition to these limitations, ages of the study populations also varied. All participants across studies were healthy, ASA status 1 or 2, but ages varied greatly. Between all six studies, ages varied from 18 to 65 . Participants of similar age groups may have made the results more generalizable. Although these limitations existed, the purpose of this systematic review was achieved. 
Despite limitations, this systematic review provides evidence that intrathecal dexmedetomidine as an adjuvant to bupivacaine will improve postoperative pain. Next, recommendations and implications for advanced practice nursing will be discussed. 


\section{Recommendations and Implications for Advanced Nursing Practice}

Management of postoperative pain is an important aspect of care for every surgical patient. Certified Registered Nurse Anesthetists (CRNAs) play an integral role in the management of postoperative pain. Adequate pain control is a crucial component of patient recovery. Pain can diminish a patient's ability to participate in postoperative interventions such as coughing, deep breathing, and ambulating (Francis \& Fitzpatrick, 2012). All these interventions can facilitate a fast, un-complicated recovery and improve patient outcomes.

There are many methods used to treat postoperative pain. These methods are key in facilitating positive patient outcomes following surgical procedures. There is no consensus on the best method for controlling pain, but health care providers must stay abreast of current methods used for postoperative pain management (Banks, 2017). One method to control postoperative pain is administration of spinal anesthesia. This method is regularly used by CRNAs for a variety of surgical procedures. There are standard medications recommended for use intrathecally, including bupivacaine. Of recent years, there has been increased use of adjuvant medications used intrathecally. One of these adjuvant medications is dexmedetomidine.

This systematic review researched the most current evidence regarding the use of dexmedetomidine as an adjuvant to intrathecal bupivacaine. The review provides evidence that intrathecal dexmedetomidine, as an adjuvant to bupivacaine, will improve postoperative pain. Applying this evidence to practice is the next step. Anesthesia providers need to be educated on the valuable effects of this intervention. Once education has taken place, the intervention can be applied at the clinical level. Once the 
intervention is applied, patients should be evaluated in the postoperative period for both positive and negative effects of intrathecal dexmedetomidine. This change in practice would be a simple one to implement if adequate education was provided to the anesthesia care team.

It is important that CRNA practice is evidence-based. For years, systematic reviews have been utilized by Advanced Practice Nurses to formulate guidelines of care. This systematic review could aid in future research regarding improved management of postoperative pain.

The use of dexmedetomidine as an adjuvant to intrathecal bupivacaine has been proposed, but further research and education needs to be provided on the topic. Further research about the dose of dexmedetomidine would be beneficial. All trials proposed in this review used slightly different doses of dexmedetomidine, and all addressed the need for further research on the matter. Identifying a specific dose could improve guidelines for easier implementation.

Future recommendations include the addition of adjuvant medications to local anesthetics intraoperatively. Published studies have supported the hypothesis that dexmedetomidine as an adjuvant medication to intrathecal bupivacaine will improve postoperative pain. Although more research on the dose of dexmedetomidine is required, benefits of the intervention have been supported. 


\section{References}

Abdelhamid SA, \& El-lakany MH (2013) Intrathecal dexmedetomidine: Useful or not? J Anesth Clin Res 4:351. doi: 10.4172/2155-6148.1000351

Banks, A. (2007). Innovations in postoperative pain management: Continuous infusion of local anesthetics. AORN Journal, 85(5), 904-918. doi:10.1016/j.aorn.2007.04.008

Bi, Y.-H., Cui, X.-G., Zhang, R.-Q., Song, C.-Y., \& Zhang, Y.-Z. (2017). Low dose of dexmedetomidine as an adjuvant to bupivacaine in cesarean surgery provides better intraoperative somato-visceral sensory block characteristics and postoperative analgesia. Oncotarget, 8(38), 63587-63595. http://doi.org.ric.idm.oclc.org/10.18632/oncotarget.18864

Butterworth, J.F., Mackey, D.C., \& Wasnick, J.D. (2013). Morgan and Mikhail's Clinical Anesthesiology, $5^{\text {th }}$ edition. McGraw-Hill Education / Medical.

Chakraborty, S., Chakrabarti, J., Mandal, M.C., Hazra, A., \& Das, S. (2010). Effect of clonidine as adjuvant in bupivacaine-induced supraclavicular brachial plexus block: A randomized controlled trial. Indian Journal of Pharmacology, 42(2), 74-77. http://doi.org/10.4103/0253-7613.64498.

Chou, R., Gordon, D. B., De, O. A., Rosenberg, J. M., Bickler, S., Brennan, T., ... Wu, C. L. (2016). Management of postoperative pain: A clinical practice guideline from the American pain society, the American society of regional anesthesia and pain medicine, and the American society of anesthesiologists' committee on regional anesthesia, executive committee, and administrative council. The Journal of Pain, 17(2), 131-137.

https://doi.org/10.1016/j.jpain.2015.12.008 
Coll, A.M., Ameen, J.R., \& Mead, D. (2004). Postoperative pain assessment tools in day surgery: Literature review. Journal of Advanced Nursing, 46(2), 124-133.

Das, A., Halder, S., Chattopadhyay, S., Mandal, P., Chhaule, S., \& Banu, R. (2015). Effect of two different doses of dexemedetomidine as adjuvant in bupivacaine induced subarachnoid block for elective abdominal hysterectomy operations: A prospective, double blind, randomized controlled study. Oman Medical Journal, 30(4), 257-263. Doi:10.5001/omj.2015.52

Desmet, M., Braems. H., Reynovoet, M., Van Caulwelaert, J., Pottel, H., Carlier, S., Missant, C., \& Van de Velde, M. (2013). I.V. and perineural dexamethasone are equivalent in increasing the analgesic duration of a single-shot interscalene block with ropivacaine for shoulder surgery: A prospective, randomized, placebo-controlled study. BJA: The British Journal Of Anaesthesia, 111(3), 445452. Doi:bja/aet109

Desmet, M., Vanneste, B., Reynovoet, M., Van Caulwelaert, J., Verhelest, L., Pottel, H., Missant, C., \&Van de Velde, M. (2015) A randomized controlled trial of intravenous dexamethasone combined with interscalene brachial plexus blockade for shoulder surgery. Anaesthesia, 70(10), 1180-1185. Doi:10.1111/anae.13156

Dubin, A. E., \& Patapoutian, A. (2010). Nociceptors: The sensors of the pain pathway. The Journal of Clinical Investigation, 120(11), 3760-3772. http://doi.org/10.1172/JCI42843

Francis L., \& Fitzpatrick, J.J. (2012). Postoperative pain: Nurse's knowledge and patient's experiences. Pain Management Nursing, 14(4), 351-357. 
Gan, T. J. (2017). Poorly controlled postoperative pain: Prevalence, consequences, and prevention. Journal of Pain Research, 10, 2287-2298. http://doi.org/10.2147/JPR.S144066

Garimella, V., \& Cellini, C. (2013). Postoperative pain control. Clinics in Colon and Rectal Surgery, 26(3), 191-196. http://doi.org/10.1055/s-0033-1351138

Gorniak, M., Proost, J.H., Veckeneer, V.C., Mulder, V.C., \& Wubbels, R.J. (2014). Clonidine as an adjuvant to prolong local analgesia in conventional scleral buckle surgery. Journal of Ocular Pharmacology and Therapeutics, 30(9), 777782. Doi:10.1089/jop.2013.0243

Hjermstad, M.J., Fayers, P.M., Haugen, D.F., Caraceni, A., Hanks, G.W., Loge, J.H., ... Kaasa, S. (2011). Studies comparing numerical rating scales, verbal rating scales, and visual analogue scales for assessment of pain intensity in adults: A systematic literature review. Journal of Pain and Symptom Management, 41(6), 1073-1093.

International Association for the Study of Pain (IASP) Terminology (2012). Retrieved from https://www.iasppain.org/terminology?navItemNumber=576\#Pain

Kim, J.E., Kim, N.Y., Lee, H.S., \& Kil, H.K. (2013). Effects of intrathecal dexmedetomdine on low-dose bupivacaine spinal anesthesia in elderly patients undergoing transurethral prostatectomy. The Pharmaceutical Society of Japan, $36(6), 959-965$.

Merksey, H., \& Bogduk, N. (2012, May 22). Classification of chronic pain. Retrieved July 11, 2017, from https://www.iasp-pain.org/Taxonomy?navItemNumber=576 
Moher, D., Liberati, A., Tetzlaff, J., Altman, D.G., \& the PRISMA Group. (2009). Preferred reporting items for systematic reviews and meta-analyses: The PRISMA statement. Annals of Internal Medicine, 151(4), 264-270.

Nazir, N., \& Jain, S. (2016). A randomized controlled trial study on the effect of adding dexmedetomidine to bupivacaine in supraclavicular block using ultrasound guidance. Ethiopian Journal of Health Sciences, 26(6), 561-566.

Doi:http://dx.doi.org/10.4314/ejhs.v26i6.9

Paganelli, M. A., \& Popescu, G. K. (2015). Actions of bupivacaine, a widely used local anesthetic, on NMDA receptor responses. Journal of Neuroscience, 35(2), 831842. doi:10.1523/jneurosci.3578-14.2015

Patro, S.S., Deshmukh, H., Ramani, Y.R., \& Das, G. (2016). Evaluation of dexmedetomidine as an adjuvant to intrathecal bupivacaine in infraumbilical surgeries. Journal of Clinical and Diagnostic Research, 10(3), 13-16.

Rodriguez, L. (2015). Pathophysiology of Pain: Implications for Perioperative Nursing. AORN Journal, 101(3), 338-344. doi:10.1016/j.aorn.2014.12.008

Salem, R.A., DArweesh, E.I., Wanis, M.A., \& Mohamed, A.A. (2015). Evaluation of the effects of intrathecal bupivacaine-dexmedetomidine for lumbar spine fusion: A double blinded randomized controlled study. European Review for Medical and Pharmacological Sciences, 19, 4542-4548.

Singh, J. (2013). Critical Appraisal Skills Programme. Journal of Pharmacology and Pharmacotherapeutics, 4(1), 76-77. 
Wiles, M.D., \& Nathanson, M.H. (2010). Local anesthetics and adjuvants-future developments. Journal of the Association of Anaesthetists of Great Britain and Ireland, 65(s1), 22-37. doi:10.1111/j.1365-2044.2009.06201.x

Yektaş, A., \& Belli, E. (2014). The effects of $2 \mu \mathrm{g}$ and $4 \mu \mathrm{g}$ doses of dexmedetomidine in combination with intrathecal hyperbaric bupivacaine on spinal anesthesia and its postoperative analgesic characteristics. Pain Research \& Management: The Journal of the Canadian Pain Society, 19(2), 75-81. 


\section{Appendix A}

\section{PRISMA 2009 Checklist}

\begin{tabular}{|c|c|c|c|}
\hline Section/topic & $\#$ & Checklist item & $\begin{array}{l}\text { Reported } \\
\text { on page \# }\end{array}$ \\
\hline \multicolumn{4}{|l|}{ TITLE } \\
\hline Title & 1 & Identify the report as a systematic review, meta-analysis, or both. & \\
\hline \multicolumn{4}{|l|}{ ABSTRACT } \\
\hline Structured summary & 2 & $\begin{array}{l}\text { Provide a structured summary including, as applicable: background; objectives; data sources; study eligibility criteria, } \\
\text { participants, and interventions; study appraisal and synthesis methods; results; limitations; conclusions and } \\
\text { implications of key findings; systematic review registration number. }\end{array}$ & \\
\hline \multicolumn{4}{|l|}{ INTRODUCTION } \\
\hline Rationale & 3 & Describe the rationale for the review in the context of what is already known. & \\
\hline Objectives & 4 & $\begin{array}{l}\text { Provide an explicit statement of questions being addressed with reference to participants, interventions, comparisons, } \\
\text { outcomes, and study design (PICOS). }\end{array}$ & \\
\hline \multicolumn{4}{|l|}{ METHODS } \\
\hline Protocol and registration & 5 & $\begin{array}{l}\text { Indicate if a review protocol exists, if and where it can be accessed (e.g., Web address), and, if available, provide } \\
\text { registration information including registration number. }\end{array}$ & \\
\hline Eligibility criteria & 6 & $\begin{array}{l}\text { Specify study characteristics (e.g., PICOS, length of follow-up) and report characteristics (e.g., years considered, } \\
\text { language, publication status) used as criteria for eligibility, giving rationale. }\end{array}$ & \\
\hline Information sources & 7 & $\begin{array}{l}\text { Describe all information sources (e.g., databases with dates of coverage, contact with study authors to identify } \\
\text { additional studies) in the search and date last searched. }\end{array}$ & \\
\hline Search & 8 & $\begin{array}{l}\text { Present full electronic search strategy for at least one database, including any limits used, such that it could be } \\
\text { repeated. }\end{array}$ & \\
\hline Study selection & 9 & $\begin{array}{l}\text { State the process for selecting studies (i.e., screening, eligibility, included in systematic review, and, if applicable, } \\
\text { included in the meta-analysis). }\end{array}$ & \\
\hline Data collection process & 10 & $\begin{array}{l}\text { Describe method of data extraction from reports (e.g., piloted forms, independently, in duplicate) and any processes } \\
\text { for obtaining and confirming data from investigators. }\end{array}$ & \\
\hline Data items & 11 & $\begin{array}{l}\text { List and define all variables for which data were sought (e.g., PICOS, funding sources) and any assumptions and } \\
\text { simplifications made. }\end{array}$ & \\
\hline $\begin{array}{l}\text { Risk of bias in individual } \\
\text { studies }\end{array}$ & 12 & $\begin{array}{l}\text { Describe methods used for assessing risk of bias of individual studies (including specification of whether this was } \\
\text { done at the study or outcome level), and how this information is to be used in any data synthesis. }\end{array}$ & \\
\hline Summary measures & 13 & State the principal summary measures (e.g., risk ratio, difference in means). & \\
\hline Synthesis of results & 14 & $\begin{array}{l}\text { Describe the methods of handling data and combining results of studies, if done, including measures of consistency } \\
\text { (e.g., } I^{2} \text { for each meta-analysis. }\end{array}$ & \\
\hline
\end{tabular}

\section{PRISMA 2009 Checklist}

\begin{tabular}{|c|c|c|c|}
\hline Section/topic & \# & Checklist item & $\begin{array}{l}\text { Reported } \\
\text { on page \# }\end{array}$ \\
\hline Risk of bias across studies & 15 & $\begin{array}{l}\text { Specify any assessment of risk of bias that may affect the cumulative evidence (e.g., publication bias, selective } \\
\text { reporting within studies). }\end{array}$ & \\
\hline Additional analyses & 16 & $\begin{array}{l}\text { Describe methods of additional analyses (e.g., sensitivity or subgroup analyses, meta-regression), if done, indicating } \\
\text { which were pre-specified. }\end{array}$ & \\
\hline \multicolumn{4}{|l|}{ RESULTS } \\
\hline Study selection & 17 & $\begin{array}{l}\text { Give numbers of studies screened, assessed for eligibility, and included in the review, with reasons for exclusions at } \\
\text { each stage, ideally with a flow diagram. }\end{array}$ & \\
\hline Study characteristics & 18 & $\begin{array}{l}\text { For each study, present characteristics for which data were extracted (e.g., study size, PICOS, follow-up period) and } \\
\text { provide the citations. }\end{array}$ & \\
\hline Risk of bias within studies & 19 & Present data on risk of bias of each study and, if available, any outcome level assessment (see item 12). & \\
\hline Results of individual studies & 20 & $\begin{array}{l}\text { For all outcomes considered (benefits or harms), present, for each study: (a) simple summary data for each } \\
\text { intervention group (b) effect estimates and confidence intervals, ideally with a forest plot. }\end{array}$ & \\
\hline Synthesis of results & 21 & Present results of each meta-analysis done, including confidence intervals and measures of consistency. & \\
\hline Risk of bias across studies & 22 & Present results of any assessment of risk of bias across studies (see Item 15). & \\
\hline Additional analysis & 23 & Give results of additional analyses, if done (e.g., sensitivity or subgroup analyses, meta-regression [see Item 16]). & \\
\hline \multicolumn{4}{|l|}{ DISCUSSION } \\
\hline Summary of evidence & 24 & $\begin{array}{l}\text { Summarize the main findings including the strength of evidence for each main outcome; consider their relevance to } \\
\text { key groups (e.g., healthcare providers, users, and policy makers). }\end{array}$ & \\
\hline Limitations & 25 & $\begin{array}{l}\text { Discuss limitations at study and outcome level (e.g., risk of bias), and at review-level (e.g., incomplete retrieval of } \\
\text { identified research, reporting bias). }\end{array}$ & \\
\hline Conclusions & 26 & Provide a general interpretation of the results in the context of other evidence, and implications for future research. & \\
\hline \multicolumn{4}{|l|}{ FUNDING } \\
\hline Funding & 27 & $\begin{array}{l}\text { Describe sources of funding for the systematic review and other support (e.g., supply of data); role of funders for the } \\
\text { systematic review. }\end{array}$ & \\
\hline
\end{tabular}

(Moher et al., 2009) 


\section{Appendix B}

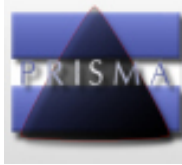

\section{PRISMA 2009 Flow Diagram}

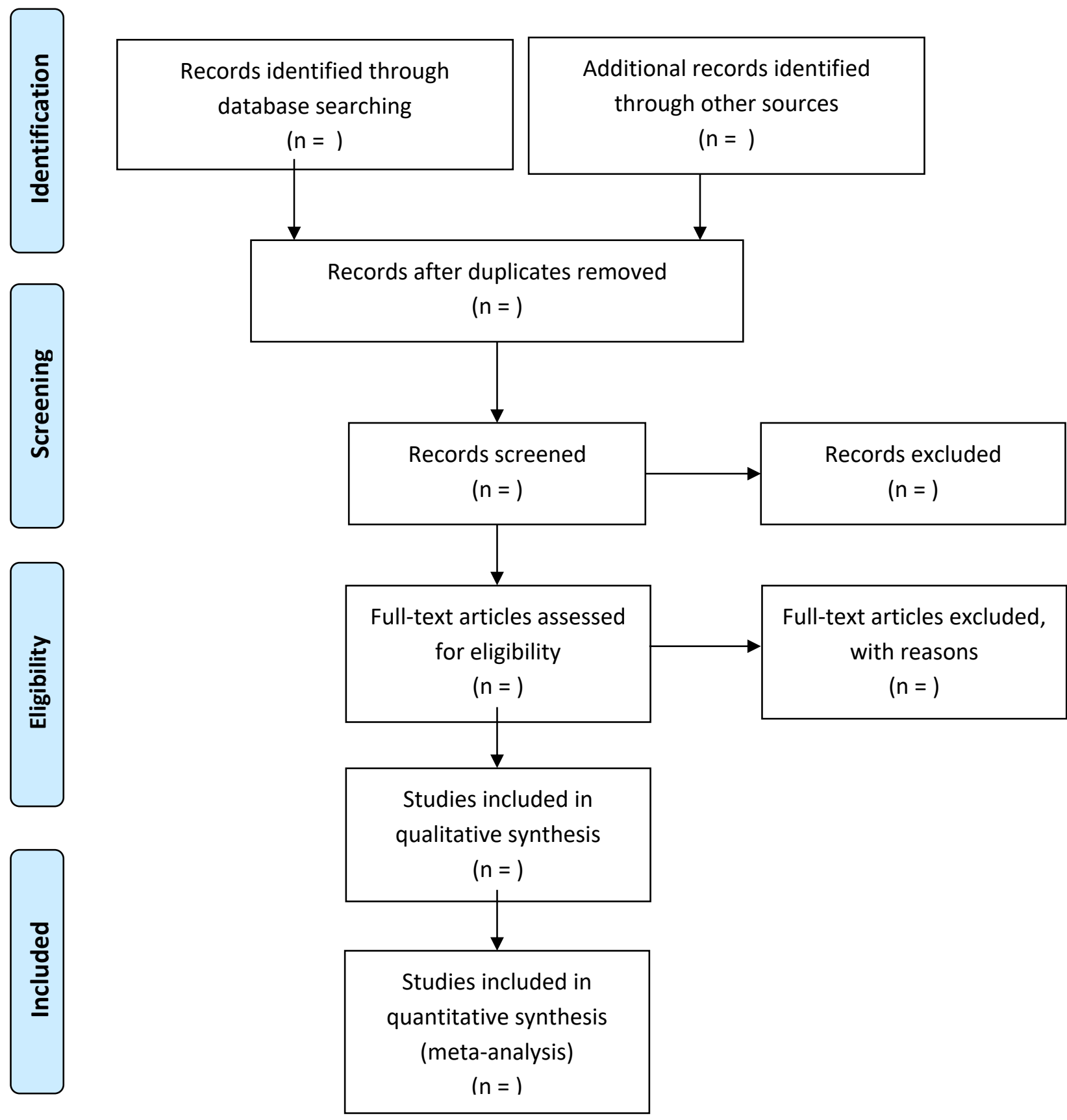

(Moher et al., 2009) 


\section{Appendix C}

\begin{tabular}{|c|c|c|c|c|}
\hline & 11 Questions & Yes & $\begin{array}{l}\text { Can't } \\
\text { tell }\end{array}$ & no \\
\hline 1 & Did the trial address a clearly focused issue? & & & \\
\hline 2 & Was the assignment of patients to treatments randomized? & & & \\
\hline 3 & $\begin{array}{l}\text { Were all the patients who entered the trial properly accounted for at } \\
\text { its conclusion? }\end{array}$ & & & \\
\hline 4 & $\begin{array}{l}\text { Were patients, health workers and study personnel 'blind' to } \\
\text { treatment? }\end{array}$ & & & \\
\hline 5 & Were the groups similar at the start of the trial? & & & \\
\hline 6 & $\begin{array}{l}\text { Aside from the experimental intervention, were the groups treated } \\
\text { equally? }\end{array}$ & & & \\
\hline 7 & How large was the treatment effect? & & & \\
\hline 8 & How precise was the estimate of the treatment effect? & & & \\
\hline 9 & $\begin{array}{l}\text { Can the results be applied in your context? (or to the local } \\
\text { population?) }\end{array}$ & & & \\
\hline 10 & Were all clinically important outcomes considered? & & & \\
\hline 11 & Are the benefits worth the harms and costs? & & & \\
\hline
\end{tabular}

(CASP, 2018) 


\section{Appendix D}

\section{$\underline{\text { Table } 1}$}

Kim, J.E., Kim, N.Y., Lee, H.S., \& Kil, H.K. (2013). Effects of intrathecal dexmedetomidine on low-dose bupivacaine spinal anesthesia in elderly patients undergoing transurethral prostatectomy. The Pharmaceutical Society of Japan, 36(6), 959-965.

\begin{tabular}{|c|c|c|c|}
\hline Purpose & Setting & Sample & Design Method \\
\hline $\begin{array}{l}\text {-Evaluate adjuvant } \\
\text { effects of intrathecal } \\
\text { dexmedetomidine in } \\
\text { elderly patients } \\
\text { undergoing TURP } \\
\text { surgery with low dose } \\
\text { bupivacaine spinal } \\
\text { anesthesia } \\
\text {-Primary end-point: } \\
\text { time to regression of 2- } \\
\text { sensory dermatomes } \\
\text { from peak sensory } \\
\text { block level } \\
\text {-Secondary end-points: } \\
\text { motor block scales at } \\
\text { peak sensory block and } \\
\text { postoperative analgesic } \\
\text { requirement }\end{array}$ & $\begin{array}{l}\text {-Approved by } \\
\text { the Institutional } \\
\text { Ethics } \\
\text { Committee of } \\
\text { Yonsei } \\
\text { University } \\
\text { Health System of } \\
\text { Japan } \\
\text {-Conducted at } \\
\text { one hospital }\end{array}$ & $\begin{array}{l}\text {-54 elderly } \\
\text { patients, ages } 60 \text { - } \\
74 \\
\text {-Patient } \\
\text { characteristics } \\
\text { were similar; } \\
\text { 39/54 had more } \\
\text { than one systemic } \\
\text { disease } \\
\text {-All patients } \\
\text { completed study }\end{array}$ & $\begin{array}{l}\text {-Participants } \\
\text { randomized into } \\
\text { one of two groups: } \\
\text { a group that } \\
\text { received 3mcg of } \\
\text { dexmedetomidine } \\
\text { combined with } \\
6 \text { mg of hyperbaric } \\
\text { bupivacaine, and } \\
\text { another group that } \\
\text { received the same } \\
\text { amount of NS and } \\
\text { bupivacaine } \\
\text {-A random number } \\
\text { sequence was used } \\
\text {-In the PACU, the } \\
\text { time to first } \\
\text { analgesic request } \\
\text { was recorded }\end{array}$ \\
\hline
\end{tabular}

$\underline{\text { Table } 2}$

\begin{tabular}{|l|l|l|l|}
\hline Procedure & Pain Scale Used/ & Results & Limitations \\
\hline
\end{tabular}




\begin{tabular}{|c|c|c|c|}
\hline $\begin{array}{l}\text { TURP surgery. } \\
\text { Spinal puncture } \\
\text { was performed at } \\
\text { L3-4 or L4-5 with } \\
\text { a midline } \\
\text { approach using a } \\
\text { 25G Quincke } \\
\text { needle in the } \\
\text { lateral decubitus } \\
\text { position. After } \\
\text { confirmation of } \\
\text { free flow and } \\
\text { clear } \\
\text { cerebrospinal } \\
\text { fluid, the drug } \\
\text { was administered, } \\
\text { and patient was } \\
\text { placed in the } \\
\text { supine position. }\end{array}$ & $\begin{array}{l}\text {-VAS } \\
\text {-assessed pain } \\
\text { level: arrival to } \\
\text { PACU, } 30 \text { minutes } \\
\text { after arrival, and } \\
\text { then } 6 \mathrm{~h}, 24 \mathrm{~h} \text {, and } \\
\text { 36h after discharge. } \\
\text {-Time to first } \\
\text { analgesic request } \\
\text { was recorded. }\end{array}$ & $\begin{array}{l}\text { Number of } \\
\text { patients requiring } \\
\text { postoperative } \\
\text { analgesics } \\
\text { weren't different } \\
\text { between the two } \\
\text { groups, but } \\
\text { dexmedetomidine } \\
\text { group had less } \\
\text { requirements for } \\
\text { postoperative } \\
\text { rescue analgesics } \\
\text { (p }<0.01 \text { ) } \\
\text {-Time to request } \\
\text { for first analgesic } \\
\text { was longer in } \\
\text { dexmedetomidine } \\
\text { group (p 0.039) } \\
\text {-3mcg of } \\
\text { dexmedetomidine } \\
\text { added to } \\
\text { bupivacaine } \\
\text { prolonged } \\
\text { postoperative } \\
\text { analgesia } \\
\text {-mean time to } \\
\text { first analgesic } \\
\text { request was } 345 \\
\text { minutes in control } \\
\text { group and } 1360 \\
\text { minutes in } \\
\text { intervention } \\
\text { group }\end{array}$ & $\begin{array}{l}\text { Three participants in the } \\
\text { control group required } \\
\text { fentanyl supplementation } \\
\text { during the procedure; } \\
\text { intervention not applied to } \\
\text { all participants }\end{array}$ \\
\hline
\end{tabular}




\section{Appendix E}

\section{Table 1}

Abdelhamid SA, El-lakany MH (2013) Intrathecal dexmedetomidine: Useful or not? $J$ Anesth Clin Res 4:351.

\begin{tabular}{|c|c|c|c|}
\hline Purpose & Setting & Sample & Design Method \\
\hline $\begin{array}{l}\text {-Evaluate role of } \\
\text { dexmedetomidine } \\
\text { when added to heavy } \\
\text { bupivacaine } \\
\text {-assess time to require } \\
\text { first analgesic } \\
\text {-assess total analgesic } \\
\text { consumption }\end{array}$ & $\begin{array}{l}\text {-Approved by the } \\
\text { Ethical } \\
\text { Committee of the } \\
\text { Medical Research } \\
\text { Institute of } \\
\text { Alexandria } \\
\text { University } \\
\text { Conducted at one } \\
\text { hospital }\end{array}$ & $\begin{array}{l}\text {-62 patients } \\
\text { presenting for } \\
\text { inguinal hernia } \\
\text { repair } \\
\text {-during period of } \\
\text { January 1, } 2013 \text { to } \\
\text { end of March } 2013 \\
\text {-ages 18-60 } \\
\text {-exclusion criteria: } \\
\text { neurological } \\
\text { disease, } \\
\text { coagulopathy, } \\
\text { cardiac disease, } \\
\text { obesity, } \\
\text { hypertension }\end{array}$ & $\begin{array}{l}\text {-patients } \\
\text { randomized into } \\
\text { one of two groups } \\
\text { using sealed } \\
\text { envelope technique } \\
\text {-group one: } 3.5 \mathrm{ml} \\
\text { of hyperbaric } \\
\text { bupivacaine and } \\
\text { 5mcg of } \\
\text { dexmedetomidine } \\
\text {-Group two: } \\
\text { normal saline } \\
\text { added to } \\
\text { hyperbaric } \\
\text { bupivacaine } \\
\text {-first time to } \\
\text { require analgesia } \\
\text { was recorded } \\
\text {-total analgesic } \\
\text { consumption was } \\
\text { recorded over } 24 \\
\text { hours }\end{array}$ \\
\hline
\end{tabular}

\section{Table 2}

\begin{tabular}{|c|c|c|c|}
\hline Procedure & $\begin{array}{l}\text { Pain Scale } \\
\text { Used }\end{array}$ & Results & Limitations \\
\hline $\begin{array}{l}\text {-25-gauge } \\
\text { pencil point } \\
\text { spinal needle } \\
\text { was inserted } \\
\text { through L4-L5 } \\
\text { interspace } \\
\text {-Injections } \\
\text { given over } 10 \\
\text { seconds }\end{array}$ & $\begin{array}{l}\text {-no pain scale } \\
\text { used } \\
\text {-results were } \\
\text { assessed by } \\
\text { evaluating time } \\
\text { to analgesic } \\
\text { request }\end{array}$ & $\begin{array}{l}\text {-analgesia } \\
\text { requirements lower } \\
\text { in group D } \\
(\mathrm{p}<0.0001) \\
\text {-total analgesic } \\
\text { consumption was } \\
\text { lower in group D } \\
(\mathrm{p}<0.0001) \\
\text {-mean time to first } \\
\text { analgesic in group } \\
1 \text { was } 259 \text { min, and } \\
381 \text { min in group } 2\end{array}$ & $\begin{array}{l}\text {-no pain scale was used } \\
\text {-no information on how pain } \\
\text { assessment was conducted }\end{array}$ \\
\hline
\end{tabular}




\section{Appendix F}

\section{Table 1}

Yektaş, A., \& Belli, E. (2014). The effects of $2 \mu \mathrm{g}$ and $4 \mu \mathrm{g}$ doses of dexmedetomidine in combination with intrathecal hyperbaric bupivacaine on spinal anesthesia and its postoperative analgesic characteristics. Pain Research \& Management: The Journal of the Canadian Pain Society, 19(2), 75-81.

\begin{tabular}{|l|l|l|l|}
\hline \multicolumn{1}{|c|}{ Purpose } & \multicolumn{1}{|c|}{ Setting } & \multicolumn{1}{c|}{ Sample } & \multicolumn{1}{c|}{ Design Method } \\
\hline -compare & -study was approved & -60 male patients & -patients were \\
postoperative & by the local ethics & undergoing inguinal & randomly divided \\
analgesic & committee of First & surgery & into three groups \\
characteristics of & University Medical & -between 20-30 & -Group 1: 15mg of \\
dexmedetomidine & Faculty of Turkey & years old & hyperbaric \\
added to hyperbaric & -conducted in a & -exclusion criteria: & bupivacaine plus \\
bupivacaine & military hospital & addicted to drugs, & 0.5ml saline \\
-compare side effects & & required additional & -Group 2: 15mg of \\
when & analgesia, sedation & hyperbaric \\
dexmedetomidine is & & during previous & bupivacaine plus 2 \\
added to intrathecal & & procedures, & mcg \\
bupivacaine & experienced pain & dexmedetomidine \\
-evaluate effects of & with previous & -Group 3: 15mg of \\
intrathecal & procedures, patients & hyperbaric \\
dexmedetomidine on & & whom they were & bupivacaine plus \\
spinal anesthesia & unable to obtain & 4mcg \\
& & CSF, and patients & dexmedetomidine \\
& whose level of & -pain onset time in \\
& & education was below & postoperative period \\
& & graduation from & was recorded \\
& & primary school & -total amount of \\
& & & analgesic medication \\
& & & for 24 hours was \\
& & & \\
& & &
\end{tabular}

$\underline{\text { Table } 2}$

\begin{tabular}{|c|c|c|c|}
\hline Procedure & $\begin{array}{l}\text { Pain Scale } \\
\text { Used }\end{array}$ & Results & Limitations \\
\hline $\begin{array}{l}\text {-patient in } \\
\text { sitting position; } \\
\text { 25-gauge } \\
\text { Quincke spinal } \\
\text { needle inserted } \\
\text { into the L4-L5 } \\
\text { disc space }\end{array}$ & $\begin{array}{l}\text {-numerical } \\
\text { pain rating } \\
\text { scale }\end{array}$ & $\begin{array}{l}\text {-time to initiation of pain } \\
\text { was significantly longer in } \\
\text { group } 3 \text { than in both groups } \\
1 \text { and } 2(\mathrm{P}<0.001) \\
\text {-analgesic medication } \\
\text { consumption over } 24 \text { hours } \\
\text { was significantly higher in }\end{array}$ & None stated \\
\hline
\end{tabular}




\begin{tabular}{|l|l|l|}
\hline -when CSF & group 1 than in groups 2 and \\
flow observed, & $3(\mathrm{P}<0.001)$ \\
prepared & -mean time to first analgesic & \\
medical & in group 1 was 220 min., & \\
solution was & group 2 371 min., and group & \\
injected & 31042 min & \\
\hline
\end{tabular}




\section{Appendix G}

\section{$\underline{\text { Table } 1}$}

Bi, Y.-H., Cui, X.-G., Zhang, R.-Q., Song, C.-Y., \& Zhang, Y.-Z. (2017). Low dose of dexmedetomidine as an adjuvant to bupivacaine in cesarean surgery provides better intraoperative somato-visceral sensory block characteristics and postoperative analgesia. Oncotarget, 8(38), 63587-63595.

\begin{tabular}{|c|c|c|c|}
\hline Purpose & Setting & Sample & Design Method \\
\hline $\begin{array}{l}\text { Measure effects of } \\
\text { lower doses of } \\
\text { dexmedetomidine } \\
\text { with intrathecal } \\
\text { bupivacaine on } \\
\text { postoperative pain }\end{array}$ & $\begin{array}{l}\text {-approved by the } \\
\text { institutional ethics } \\
\text { committee in } \\
\text { China }\end{array}$ & $\begin{array}{l}\text {-60 participants } \\
\text {-women of ASA } \\
\text { physical status } 1 \text { or } \\
2 \\
\text {-pregnant and } \\
\text { receiving spinal } \\
\text { anesthesia for } \\
\text { elective c-section } \\
\text {-ages } 18-40 \\
\text {-exclusion criteria: } \\
\text { history of opioid } \\
\text { use or NSAIDS, } \\
\text { psychiatric } \\
\text { disorders, } \\
\text { preoperative HR } \\
<50 \text { bpm, } \\
\text { neuromuscular or } \\
\text { endocrine disease, } \\
\text { or allergy to alpha } \\
2 \text { agonists }\end{array}$ & $\begin{array}{l}\text {-prospective, } \\
\text { randomized, double } \\
\text { blind study } \\
\text {-a computer } \\
\text { generated } \\
\text { randomization table } \\
\text { was used } \\
\text {-Bup Group: 10mg } \\
\text { bupivacaine alone } \\
\text {-Bup+Dex3 Group: } \\
\text { 10mg bupivacaine } \\
\text { with 3mcg } \\
\text { dexmedetomidine } \\
\text {-Bup+Dex5 Group: } \\
\text { 10mg bupivacaine } \\
\text { with 5mcg } \\
\text { dexmedetomidine }\end{array}$ \\
\hline
\end{tabular}

$\underline{\text { Table } 2}$

\begin{tabular}{|l|l|l|l|}
\hline \multicolumn{1}{|c|}{ Procedure } & \multicolumn{1}{|c|}{$\begin{array}{c}\text { Pain Scale } \\
\text { Used }\end{array}$} & \multicolumn{1}{c|}{ Results } & \multicolumn{1}{c|}{ Limitations } \\
\hline $\begin{array}{l}\text {-lumbar epidural } \\
\text { anesthesia was }\end{array}$ & $\begin{array}{l}\text {-VAS } \\
\text {-assessed 6 and } \\
\text { induced }\end{array}$ & $\begin{array}{l}\text {-VAS at 6 hours was higher } \\
\text { in Bup Group than the other }\end{array}$ & None stated \\
-spinal injection & surgery & two groups $(\mathrm{P}=0.0032)$ & \\
performed with & -first rescue & at 12 hours $(\mathrm{P}=0.3533)$ & \\
a 25-gauge & analgesia drug & -time to first postoperative & \\
pencil point & time was & supplemental drug & \\
needle and & recorded & administration was not & \\
injection was & & significantly different & \\
made & & (P=0.7096) & \\
& & & \\
\hline
\end{tabular}




\begin{tabular}{|l|l|ll|l|}
\hline $\begin{array}{l}\text {-study drugs } \\
\text { were injected at } \\
\text { a rate of }\end{array}$ & min & Bup Group: 1320 \\
$\begin{array}{l}1 \mathrm{ml} / 15 \mathrm{sec} \\
\text {-same }\end{array}$ & $\min$ & Bup+Dex3: 1488 & \\
$\begin{array}{l}\text { anesthesiologist } \\
\text { administered }\end{array}$ & & min & & \\
each spinal & & & & \\
\hline
\end{tabular}




\section{Appendix H}

\section{$\underline{\text { Table } 1}$}

Salem, R.A., Darweesh, E.I., Wanis, M.A., \& Mohamed, A.A. (2015). Evaluation of the effects of intrathecal bupivacaine-dexmedetomidine for lumbar spine fusion: a double blinded randomized controlled study. European Review for Medical and Pharmacological Sciences, 19, 4542-4548.

\begin{tabular}{|c|c|c|c|}
\hline Purpose & Setting & Sample & Design Method \\
\hline $\begin{array}{l}\text {-evaluate efficacy of } \\
\text { intrathecal } \\
\text { dexmedetomidine at } \\
\text { improving } \\
\text { postoperative } \\
\text { analgesia during } \\
\text { spinal surgery } \\
\text {-also investigated } \\
\text { effects of } \\
\text { dexmedetomidine } \\
\text { on patient } \\
\text { hemodynamics }\end{array}$ & $\begin{array}{l}\text {-approved by the } \\
\text { Ethics and } \\
\text { Research } \\
\text { Committee of } \\
\text { Sohag Faculty } \\
\text { Faculty of } \\
\text { Medicine, Sohag } \\
\text { University } \\
\text {-conducted at } \\
\text { Sohag University } \\
\text { Hospital } \\
\text {-August 2012-July } \\
\text { 2014 }\end{array}$ & $\begin{array}{l}\text {-52 patients } \\
\text {-ages } 40-65 \text { years } \\
\text {-ASA physical } \\
\text { status } 1 \text { or } 2 \\
\text {-scheduled for one- } \\
\text { level posterolateral } \\
\text { lumbar spine fusion } \\
\text {-exclusion criteria: } \\
\text { contraindication for } \\
\text { spinal anesthesia, } \\
\text { known allergy to } \\
\text { study drugs, } \\
\text { treatment with } \\
\text { alpha adrenergic } \\
\text { antagonists, labile } \\
\text { hypertension, } \\
\text { cardiac } \\
\text { dysrhythmias, } \\
\text { coronary artery } \\
\text { disease, renal or } \\
\text { hepatic impairment, } \\
\text { neurological } \\
\text { disorder, or } \\
\text { bleeding diathesis }\end{array}$ & $\begin{array}{l}\text {-prospective, } \\
\text { randomized, double- } \\
\text { blind, placebo- } \\
\text { controlled clinical } \\
\text { study } \\
\text {-participants were } \\
\text { randomized using } \\
\text { sequentially } \\
\text { numbered closed } \\
\text { envelopes } \\
\text {-Group D: } 15 \mathrm{mg} \\
\text { hyperbaric } \\
\text { bupivacaine with } \\
\text { 5mcg of } \\
\text { dexmedetomidine } \\
\text {-Group P: } 15 \mathrm{mg} \\
\text { hyperbaric } \\
\text { bupivacaine with } \\
\text { 0.5ml saline } \\
\text {-time to first } \\
\text { requirement of } \\
\text { analgesia was } \\
\text { recorded } \\
\text {-total dose of } \\
\text { analgesic } \\
\text { medication over } 24 \\
\text { hours was recorded }\end{array}$ \\
\hline
\end{tabular}

$\underline{\text { Table } 2}$

\begin{tabular}{|c|c|c|c|}
\hline Procedure & $\begin{array}{l}\text { Pain Scale } \\
\text { Used }\end{array}$ & Results & Limitations \\
\hline $\begin{array}{l}\text {-Lumbar } \\
\text { puncture } \\
\text { performed with } \\
\text { patient in sitting }\end{array}$ & $\begin{array}{l}\text {-no pain scale } \\
\text { used } \\
\text {-results were } \\
\text { assessed by }\end{array}$ & $\begin{array}{l}\text {-time to first } \\
\text { analgesic } \\
\text { request was } \\
\text { significantly }\end{array}$ & None stated \\
\hline
\end{tabular}




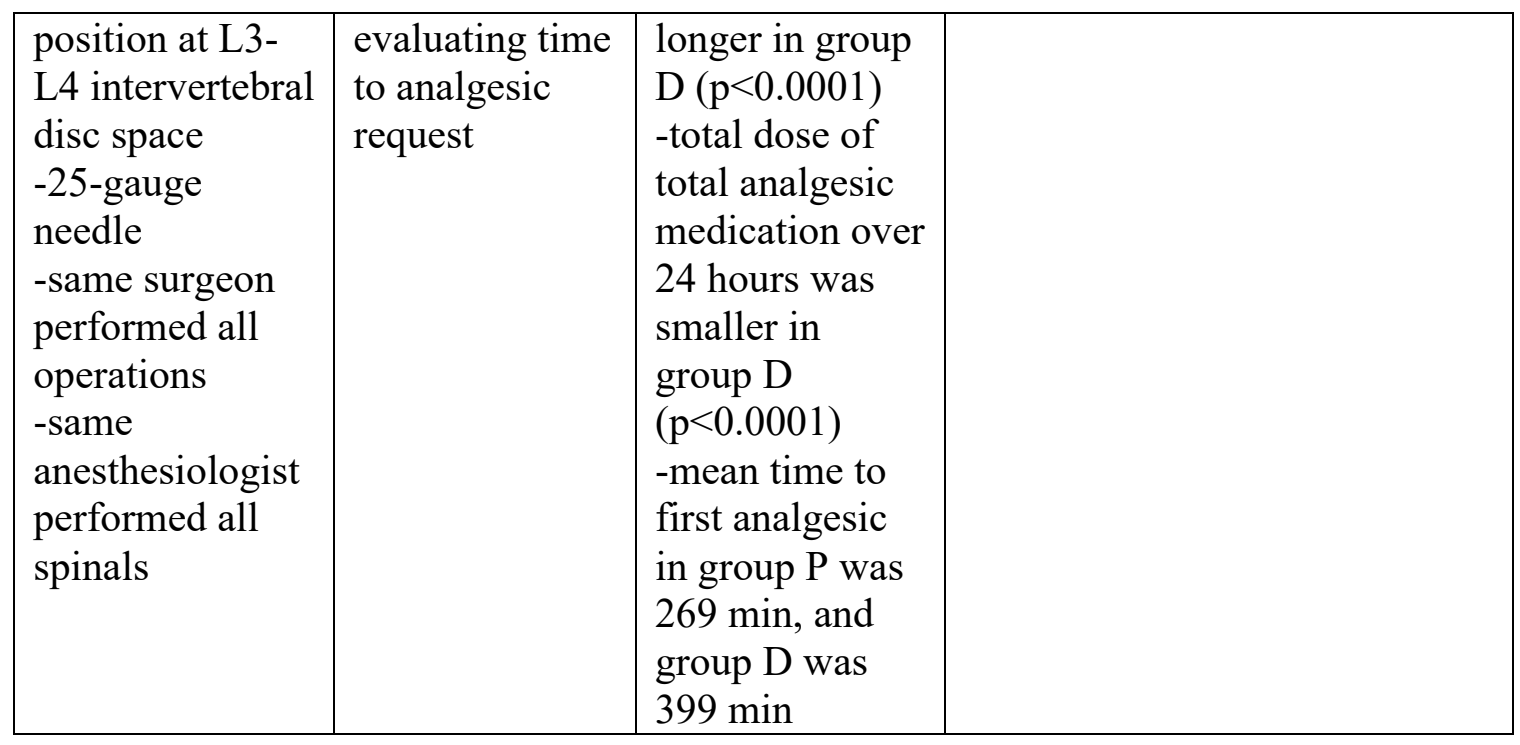




\section{Appendix I}

\section{$\underline{\text { Table } 1}$}

Patro, S.S., Deshmukh, H., Ramani, Y.R., \& Das, G. (2016). Evaluation of dexmedetomidine as an adjuvant to intrathecal bupivacaine in infraumbilical surgeries. Journal of Clinical and Diagnostic Research, 10(3), 13-16.

\begin{tabular}{|c|c|c|c|}
\hline Purpose & Setting & Sample & Design Method \\
\hline $\begin{array}{l}\text {-evaluate efficacy of } \\
\text { intrathecal } \\
\text { dexmedetomidine as } \\
\text { an adjuvant to } \\
\text { bupivacaine in } \\
\text { spinal anesthesia in } \\
\text { patients undergoing } \\
\text { infraumbilical } \\
\text { surgery }\end{array}$ & $\begin{array}{l}\text {-study approved by } \\
\text { Institutional Ethics } \\
\text { Committee of } \\
\text { Odisha, India } \\
\text {-conducted at one } \\
\text { hospital } \\
\text {-over a 2-month } \\
\text { period }\end{array}$ & $\begin{array}{l}\text {-60 adult patients } \\
\text { of either sex } \\
\text {-ages } 18-45 \\
\text {-ASA } 1 \text { and } 2 \\
\text {-exclusion criteria: } \\
\text { coagulation } \\
\text { disorders, } \\
\text { neurologic } \\
\text { disorders }\end{array}$ & $\begin{array}{l}\text {-prospective, double } \\
\text { blind } \\
\text {-randomly allocated } \\
\text { into two groups } \\
\text { using sealed } \\
\text { envelope technique } \\
\text {-Group I: } 3 \mathrm{ml} \text { of } \\
0.5 \% \text { hyperbaric } \\
\text { bupivacaine and } \\
0.5 \mathrm{ml} \text { normal saline } \\
\text {-Group II: } 3 \mathrm{ml} \text { of } \\
0.5 \% \text { hyperbaric } \\
\text { bupivacaine with } \\
5 \text { mcg } \\
\text { dexmedetomidine } \\
\text {-level of analgesia in } \\
\text { postoperative period } \\
\text { was recorded }\end{array}$ \\
\hline
\end{tabular}

Table 2

\begin{tabular}{|l|l|l|l|}
\hline Procedure & Pain Scale Used & \multicolumn{1}{|c|}{ Results } & Limitations \\
\hline -surgery was & -VAS & -significant & -small sample size \\
approximately one & & difference in & -2-month period \\
and a half hour & & duration of & \\
-medication & complete analgesia & \\
prepared by & observed between & \\
anesthesiologist not & & two groups & \\
involved in study & -intra-operative & \\
-lumbar puncture & VAS was $<3$ in & \\
performed in left & & both groups & \\
lateral position & & -after three hours & \\
-25 gauge Quincke & & VAS 0.03 in Group & \\
needle inserted at & & II and 1.03 in & \\
L3-L4 intervertebral & Group I & \\
space & -after six hours & \\
& & VAS 2.67 in Group & \\
\hline
\end{tabular}




\begin{tabular}{|l|l|l|}
\hline$-3.5 \mathrm{ml}$ of pre- & II and 3.7 in Group & \\
prepared drug & I $(\mathrm{p}<0.001)$ \\
administered & -mean time to first & \\
-infraumbilical & analgesic in group I & was 193.6 min, \\
surgeries: & group II was 333.6 & \\
hysterectomy, hernia & min & \\
repairs, & & \\
appendectomy, open & & \\
urosurgical & & \\
procedures & & \\
\hline
\end{tabular}




\section{Appendix J}

Kim, J.E., Kim, N.Y., Lee, H.S., \& Kil, H.K. (2013). Effects of intrathecal dexmedetomdine on low-dose bupivacaine spinal anesthesia in elderly patients undergoing transurethral prostatectomy. The Pharmaceutical Society of Japan, 36(6), 959-965.

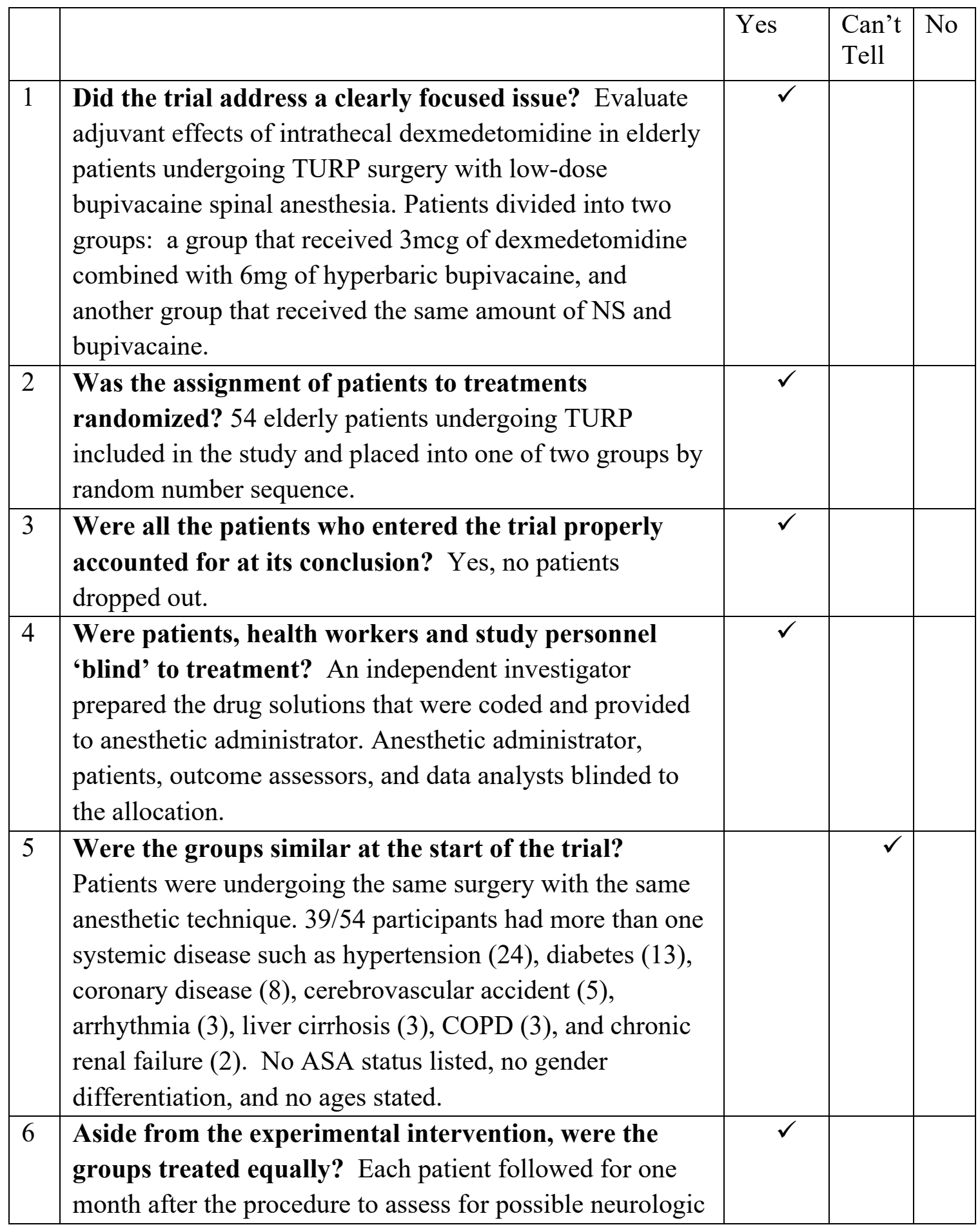




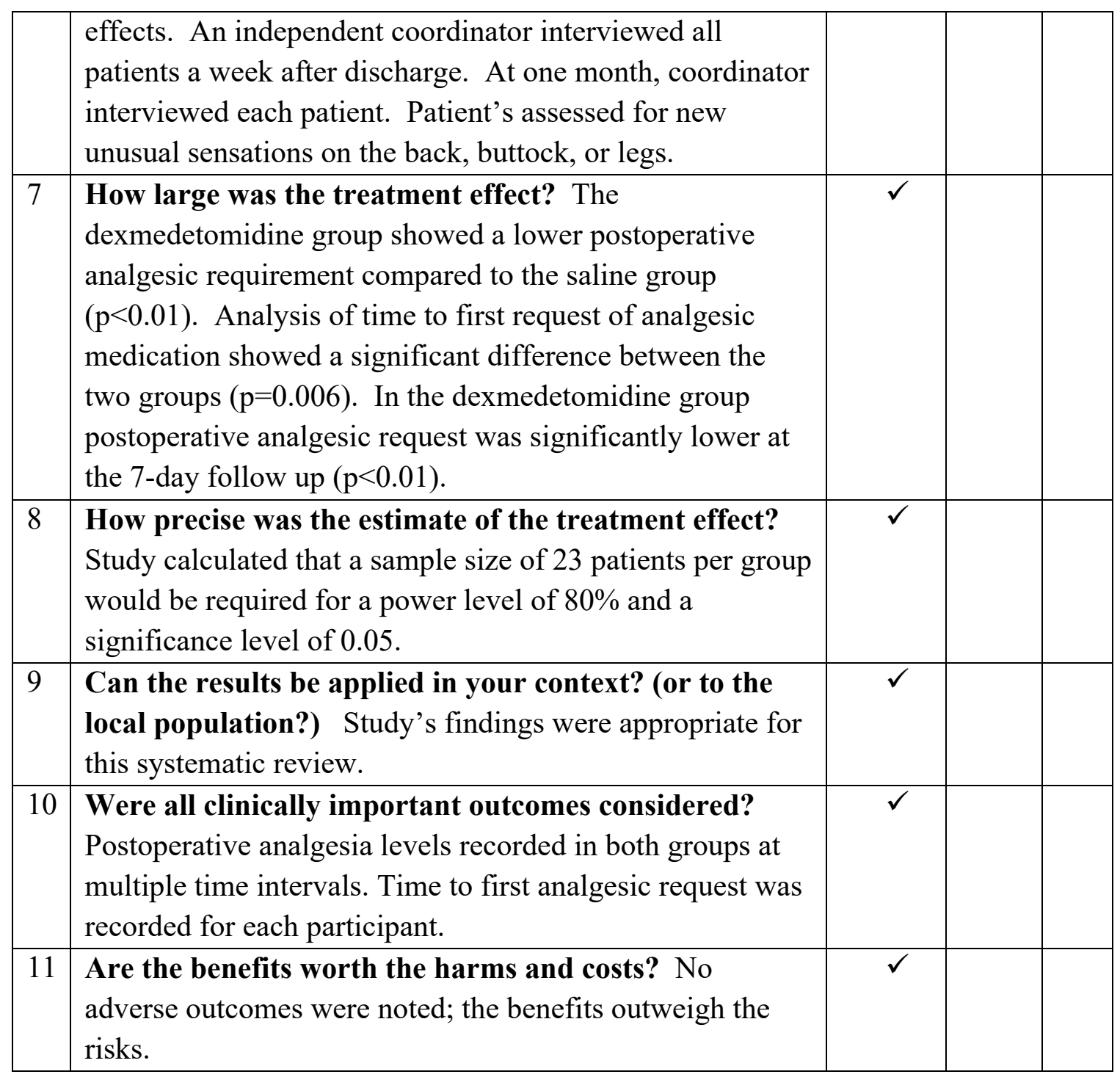




\section{Appendix K}

Abdelhamid SA, El-lakany MH (2013) Intrathecal dexmedetomidine: Useful or not? $J$ Anesth Clin Res 4:351.

\begin{tabular}{|c|c|c|c|c|}
\hline & & Yes & $\begin{array}{l}\text { Can't } \\
\text { tell }\end{array}$ & No \\
\hline 1 & $\begin{array}{l}\text { Did the trial address a clearly focused issue? Purpose } \\
\text { was to evaluate effects of adding dexmedetomidine to } \\
\text { hyperbaric bupivacaine intrathecally. End-points were } \\
\text { block characteristics among studied groups, analgesic } \\
\text { needs, and intra-operative assessment of blood pressure } \\
\text { and heart rate. }\end{array}$ & $\checkmark$ & & \\
\hline 2 & $\begin{array}{l}\text { Was the assignment of patients to treatments } \\
\text { randomized? Patients were randomly divided using } \\
\text { sealed envelope technique. }\end{array}$ & $\checkmark$ & & \\
\hline 3 & $\begin{array}{l}\text { Were all the patients who entered the trial properly } \\
\text { accounted for at its conclusion? All } 62 \text { patients finished } \\
\text { study. }\end{array}$ & $\checkmark$ & & \\
\hline 4 & $\begin{array}{l}\text { Were patients, health workers and study personnel } \\
\text { 'blind' to treatment? This was a double blinded } \\
\text { randomized control trial. Medications were prepared by a } \\
\text { third party. }\end{array}$ & $\checkmark$ & & \\
\hline 5 & $\begin{array}{l}\text { Were the groups similar at the start of the trial? } \\
\text { Patients were excluded if they had any major illnesses. } \\
\text { They were all ASA } 1 \text { or } 2 \text { status. Weights were similar, } \\
\text { between } 65-68 \text { kilograms. The only characteristic that } \\
\text { varied significantly was age, which ranged from } 22-56 \text {. }\end{array}$ & & $\checkmark$ & \\
\hline 6 & $\begin{array}{l}\text { Aside from the experimental intervention, were the } \\
\text { groups treated equally? Each group was monitored } \\
\text { throughout procedure for adverse events. Postoperatively } \\
\text { they were monitored for complications including nausea, } \\
\text { vomiting, shivering, bradycardia, and hypotension. }\end{array}$ & $\checkmark$ & & \\
\hline 7 & $\begin{array}{l}\text { How large was the treatment effect? Time to first } \\
\text { required analgesic medication in intervention group } \\
\text { obtained a } p \text { value of }<0.0001 \text {. Total analgesic } \\
\text { consumption for intervention group obtained a } p \text { value of } \\
<0.0001 \text {. }\end{array}$ & $\checkmark$ & & \\
\hline 8 & $\begin{array}{l}\text { How precise was the estimate of the treatment effect? } \\
\text { Significance of the results was at the } 5 \% \text { level of } \\
\text { significance. For the intervention group, time to first } \\
\text { analgesic request had a significance level of } Z=6.81 \text { and } \\
\text { total analgesic consumption has a significance level of } \\
Z=6.818\end{array}$ & $\checkmark$ & & \\
\hline
\end{tabular}




\begin{tabular}{|c|c|c|c|c|}
\hline 9 & $\begin{array}{l}\text { Can the results be applied in your context? (or to the } \\
\text { local population?) Findings were appropriate for this } \\
\text { systematic review. }\end{array}$ & $\checkmark$ & & \\
\hline 10 & $\begin{array}{l}\text { Were all clinically important outcomes considered? } \\
\text { Immediate outcomes were considered and evaluated, but } \\
\text { nothing beyond immediate post-operative period was } \\
\text { assessed. There was no documented follow-up with any } \\
\text { participants. }\end{array}$ & & & $\sqrt{ }$ \\
\hline 11 & $\begin{array}{l}\text { Are the benefits worth the harms and costs? Although } \\
\text { there were positive analgesia results in both groups, there } \\
\text { were also complications noted. No financial information } \\
\text { noted so it is difficult to determine if the benefit of } \\
\text { improved postoperative analgesia outweighed the risk of } \\
\text { harm and cost. }\end{array}$ & & $\checkmark$ & \\
\hline
\end{tabular}




\section{Appendix L}

Bi, Y.-H., Cui, X.-G., Zhang, R.-Q., Song, C.-Y., \& Zhang, Y.-Z. (2017). Low dose of dexmedetomidine as an adjuvant to bupivacaine in cesarean surgery provides better intraoperative somato-visceral sensory block characteristics and postoperative analgesia. Oncotarget, 8(38), 63587-63595.

\begin{tabular}{|c|c|c|c|c|}
\hline & & Yes & $\begin{array}{l}\text { Can't } \\
\text { tell }\end{array}$ & No \\
\hline 1 & $\begin{array}{l}\text { Did the trial address a clearly focused issue? Investigate } \\
\text { the beneficial effects of dexmedetomidine on postoperative } \\
\text { analgesia when combined with intrathecal bupivacaine. } \\
\text { Spinal anesthesia is commonly used for c-sections, but } \\
\text { there remains a lack of long-lasting postoperative } \\
\text { analgesia. }\end{array}$ & $\checkmark$ & & \\
\hline 2 & $\begin{array}{l}\text { Was the assignment of patients to treatments } \\
\text { randomized? A computer-generated randomization table } \\
\text { was used to divide the participants into groups. }\end{array}$ & $\checkmark$ & & \\
\hline 3 & $\begin{array}{l}\text { Were all the patients who entered the trial properly } \\
\text { accounted for at its conclusion? If spinal anesthesia } \\
\text { failed, participants would be excluded, but the study does } \\
\text { not identify how many participants were excluded; they } \\
\text { did not specify how many participants finished the study. }\end{array}$ & & $\checkmark$ & \\
\hline 4 & $\begin{array}{l}\text { Were patients, health workers and study personnel } \\
\text { 'blind' to treatment? Medication prescriptions were kept } \\
\text { in a sealed envelope, and medication was prepared by a } \\
\text { registered anesthetic nurse who was not involved in the } \\
\text { study. All employees contributing to study were blinded. }\end{array}$ & $\checkmark$ & & \\
\hline 5 & $\begin{array}{l}\text { Were the groups similar at the start of the trial? } \\
\text { Demographic profiles of participants were similar } \\
\text { regarding age, weight, height, gestation age, and mean } \\
\text { duration of surgery. }\end{array}$ & $\checkmark$ & & \\
\hline 6 & $\begin{array}{l}\text { Aside from the experimental intervention, were the } \\
\text { groups treated equally? Following procedure, all } \\
\text { participants were advised to avoid breastfeeding for } 24 \\
\text { hours; there are no published studies on the safety of } \\
\text { breastfeeding after spinal dexmedetomidine. Side } \\
\text { effects/complications were treated equally in each } \\
\text { participant. }\end{array}$ & $\checkmark$ & & \\
\hline 7 & $\begin{array}{l}\text { How large was the treatment effect? VAS at } 6 \text { hours } \\
\text { was higher in Bup Group than the other two groups } \\
(\mathrm{P}=0.0032) \text {. } \\
\text { No difference was observed at } 12 \text { hours }(\mathrm{P}=0.3533) \text {. }\end{array}$ & $\checkmark$ & & \\
\hline 8 & $\begin{array}{l}\text { How precise was the estimate of the treatment effect? } \\
\text { P-value less than } 0.05 \text { was considered statistically } \\
\text { significant. }\end{array}$ & $\checkmark$ & & \\
\hline
\end{tabular}




\begin{tabular}{|l|l|c|c|c|}
\hline 9 & $\begin{array}{l}\text { Can the results be applied in your context? (or to the } \\
\text { local population?) Findings were appropriate for this } \\
\text { systematic review. }\end{array}$ & $\checkmark$ & & \\
\hline 10 & $\begin{array}{l}\text { Were all clinically important outcomes considered? } \\
\text { Along with postoperative analgesia, other outcomes } \\
\text { assessed include fetal well-being, spinal block } \\
\text { characteristics, side effects, and maternal stress response. }\end{array}$ & $\begin{array}{l}\text { Are the benefits worth the harms and costs? There were } \\
\text { clear benefits on postoperative analgesia and no harm } \\
\text { towards the fetus or mother. Cost analysis was not } \\
\text { evaluated. }\end{array}$ & $\checkmark$ & \\
\hline 11 & & \\
\hline
\end{tabular}




\section{Appendix M}

Patro, S.S., Deshmukh, H., Ramani, Y.R., \& Das, G. (2016). Evaluation of dexmedetomidine as an adjuvant to intrathecal bupivacaine in infraumbilical surgeries. Journal of Clinical and Diagnostic Research, 10(3), 13-16.

\begin{tabular}{|c|c|c|c|c|}
\hline & & Yes & $\begin{array}{l}\text { Can't } \\
\text { tell }\end{array}$ & No \\
\hline 1 & $\begin{array}{l}\text { Did the trial address a clearly focused issue? Evaluate } \\
\text { efficacy of intrathecal dexmedetomidine as an adjuvant to } \\
\text { bupivacaine in spinal anesthesia in patients undergoing } \\
\text { infraumbilical surgery. Patients divided into two groups: } \\
\text { group I received hyperbaric bupivacaine with normal } \\
\text { saline, group II received hyperbaric bupivacaine with } \\
\text { dexmedetomidine. }\end{array}$ & $\checkmark$ & & \\
\hline 2 & $\begin{array}{l}\text { Was the assignment of patients to treatments } \\
\text { randomized? Patients were randomly allocated into two } \\
\text { groups using sealed envelope technique. }\end{array}$ & $\checkmark$ & & \\
\hline 3 & $\begin{array}{l}\text { Were all the patients who entered the trial properly } \\
\text { accounted for at its conclusion? Yes, no patients dropped } \\
\text { out. }\end{array}$ & $\checkmark$ & & \\
\hline 4 & $\begin{array}{l}\text { Were patients, health workers and study personnel } \\
\text { 'blind' to treatment? Medication was prepared by an } \\
\text { anesthesiologist not included in study. Double blind study. }\end{array}$ & $\checkmark$ & & \\
\hline 5 & $\begin{array}{l}\text { Were the groups similar at the start of the trial? } \\
\text { Demographics were comparable with respect to age, sex, } \\
\text { weight, height, duration, and type of surgery. }\end{array}$ & $\checkmark$ & & \\
\hline 6 & $\begin{array}{l}\text { Aside from the experimental intervention, were the } \\
\text { groups treated equally? All participants were treated } \\
\text { equally regarding side effects/adverse events. }\end{array}$ & $\checkmark$ & & \\
\hline 7 & $\begin{array}{l}\text { How large was the treatment effect? Postoperative VAS } \\
\text { ratings were significantly different at } 6 \text { hours between the } \\
\text { two groups, } p<0.001 \text {. }\end{array}$ & $\checkmark$ & & \\
\hline 8 & $\begin{array}{l}\text { How precise was the estimate of the treatment effect? } \\
\text { P value }<0.05 \text { was considered significant. }\end{array}$ & $\checkmark$ & & \\
\hline 9 & $\begin{array}{l}\text { Can the results be applied in your context? (or to the } \\
\text { local population?) Findings were appropriate for this } \\
\text { systematic review. }\end{array}$ & $\checkmark$ & & \\
\hline 10 & $\begin{array}{l}\text { Were all clinically important outcomes considered? } \\
\text { Time to first analgesic request was recorded; VAS ratings } \\
\text { were recorded at } 3 \text { hours, } 6 \text { hours, and } 12 \text { hours postop. }\end{array}$ & $\checkmark$ & & \\
\hline 11 & $\begin{array}{l}\text { Are the benefits worth the harms and costs? Benefits of } \\
\text { dexmedetomidine on postoperative analgesia were clear; } \\
\text { cost analysis was not performed. }\end{array}$ & & $\checkmark$ & \\
\hline
\end{tabular}




\section{Appendix N}

Salem, R.A., Darweesh, E.I., Wanis, M.A., \& Mohamed, A.A. (2015). Evaluation of the effects of intrathecal bupivacaine-dexmedetomidine for lumbar spine fusion: a double blinded randomized controlled study. European Review for Medical and Pharmacological Sciences, 19, 4542-4548.

\begin{tabular}{|c|c|c|c|c|}
\hline & & Yes & $\begin{array}{l}\text { Can't } \\
\text { tell }\end{array}$ & No \\
\hline 1 & $\begin{array}{l}\text { Did the trial address a clearly focused issue? Evaluate } \\
\text { efficacy of intrathecal dexmedetomidine at improving } \\
\text { postoperative analgesia during spinal surgery. }\end{array}$ & $\checkmark$ & & \\
\hline 2 & $\begin{array}{l}\text { Was the assignment of patients to treatments } \\
\text { randomized? Randomization and enrollment were } \\
\text { performed using sequentially numbered closed envelopes. }\end{array}$ & $\checkmark$ & & \\
\hline 3 & $\begin{array}{l}\text { Were all the patients who entered the trial properly } \\
\text { accounted for at its conclusion? } 52 \text { participants were } \\
\text { present at the start, and } 52 \text { participants at the conclusion }\end{array}$ & $\checkmark$ & & \\
\hline 4 & $\begin{array}{l}\text { Were patients, health workers and study personnel } \\
\text { 'blind' to treatment? This was a double blinded study. } \\
\text { One anesthesiologist performed the spinal blocks while } \\
\text { another followed the patients postoperatively. Both } \\
\text { anesthesiologists were blinded to group allocation. }\end{array}$ & $\checkmark$ & & \\
\hline 5 & $\begin{array}{l}\text { Were the groups similar at the start of the trial? Patient } \\
\text { demographic data did not differ between the two study } \\
\text { groups }\end{array}$ & $\checkmark$ & & \\
\hline 6 & $\begin{array}{l}\text { Aside from the experimental intervention, were the } \\
\text { groups treated equally? No other information was } \\
\text { provided on group treatment. }\end{array}$ & & $\checkmark$ & \\
\hline 7 & $\begin{array}{l}\text { How large was the treatment effect? Time to first } \\
\text { analgesic request was significantly longer in group D } \\
(p<0.0001) \text {. Total dose of total analgesic medication over } \\
24 \text { hours was smaller in group D }(p<0.0001)\end{array}$ & $\checkmark$ & & \\
\hline 8 & $\begin{array}{l}\text { How precise was the estimate of the treatment effect? } \\
\text { Level of statistical significance was considered at } p<0.05\end{array}$ & $\checkmark$ & & \\
\hline 9 & $\begin{array}{l}\text { Can the results be applied in your context? (or to the } \\
\text { local population?) Findings were appropriate for this } \\
\text { systematic review. }\end{array}$ & $\checkmark$ & & \\
\hline 10 & $\begin{array}{l}\text { Were all clinically important outcomes considered? } \\
\text { Time to first analgesic request was recorded, as well as total } \\
\text { dose of analgesic medications. }\end{array}$ & $\checkmark$ & & \\
\hline 11 & $\begin{array}{l}\text { Are the benefits worth the harms and costs? No adverse } \\
\text { outcomes were noted in the intervention group; benefits } \\
\text { outweigh the risks. Cost analysis was not done. }\end{array}$ & $\checkmark$ & & \\
\hline
\end{tabular}




\section{Appendix O}

Yektaş, A., \& Belli, E. (2014). The effects of $2 \mu \mathrm{g}$ and $4 \mu \mathrm{g}$ doses of dexmedetomidine in combination with intrathecal hyperbaric bupivacaine on spinal anesthesia and its postoperative analgesic characteristics. Pain Research \& Management: The Journal of the Canadian Pain

\begin{tabular}{|c|c|c|c|c|}
\hline & & Yes & $\begin{array}{l}\text { Can't } \\
\text { tell }\end{array}$ & No \\
\hline 1 & $\begin{array}{l}\text { Did the trial address a clearly focused issue? Evaluated } \\
\text { different doses of intrathecal dexmedetomidine and } \\
\text { whether they had effects on properties of hyperbaric } \\
\text { bupivacaine. Goal was to prolong postoperative analgesia } \\
\text { while providing quality anesthesia. }\end{array}$ & $\checkmark$ & & \\
\hline 2 & $\begin{array}{l}\text { Was the assignment of patients to treatments } \\
\text { randomized? Patients were randomly divided into three } \\
\text { groups. }\end{array}$ & $\checkmark$ & & \\
\hline 3 & $\begin{array}{l}\text { Were all the patients who entered the trial properly } \\
\text { accounted for at its conclusion? } 60 \text { male patients } \\
\text { participated and were present at conclusion of study. }\end{array}$ & $\checkmark$ & & \\
\hline 4 & $\begin{array}{l}\text { Were patients, health workers and study personnel } \\
\text { 'blind' to treatment? Double-blind study. }\end{array}$ & $\checkmark$ & & \\
\hline 5 & $\begin{array}{l}\text { Were the groups similar at the start of the trial? Ages } \\
\text { were between } 20-30 \text {, all ASA status } 1 . \text { Mean weight } \\
\text { among participants in group } 1,2 \text {, and } 3 \text { were } 72 \mathrm{~kg}, 72 \mathrm{~kg} \text {, } \\
\text { and } 73 \mathrm{~kg} \text { respectively. Mean height among participants in } \\
\text { group } 1,2 \text {, and } 3 \text { were } 174 \mathrm{~cm}, 173 \mathrm{~cm} \text {, and } 172 \mathrm{~cm} \\
\text { respectively. }\end{array}$ & $\checkmark$ & & \\
\hline 6 & $\begin{array}{l}\text { Aside from the experimental intervention, were the } \\
\text { groups treated equally? Each participant was monitored } \\
\text { throughout procedure in the same manner. Surgery } \\
\text { duration was } 20 \text { minutes for each participant. Side effects } \\
\text { were treated symptomatically with the same interventions. }\end{array}$ & $\checkmark$ & & \\
\hline 7 & $\begin{array}{l}\text { How large was the treatment effect? Time to pain onset } \\
\text { obtained a } \mathrm{P} \text { value of }<0.001 \text {. Amount of analgesic } \\
\text { medication consumption over } 24 \text { hours obtained a } \mathrm{P} \text { value } \\
\text { of }<0.001 \text {. }\end{array}$ & $\checkmark$ & & \\
\hline 8 & $\begin{array}{l}\text { How precise was the estimate of the treatment effect? } \mathrm{P} \\
<0.05 \text { was considered statistically significant. }\end{array}$ & $\checkmark$ & & \\
\hline 9 & $\begin{array}{l}\text { Can the results be applied in your context? (or to the } \\
\text { local population?) Findings were appropriate for this } \\
\text { systematic review. }\end{array}$ & $\checkmark$ & & \\
\hline 10 & $\begin{array}{l}\text { Were all clinically important outcomes considered? } \\
\text { Analgesic requirements, side effects, and complications } \\
\text { were all considered. }\end{array}$ & $\checkmark$ & & \\
\hline
\end{tabular}




\begin{tabular}{|l|l|l|r|r|}
\hline 11 & $\begin{array}{l}\text { Are the benefits worth the harms and costs? This study } \\
\text { found clear benefits of using dexmedetomidine with } \\
\text { hyperbaric bupivacaine intrathecally with no additional } \\
\text { harm to the patient, but cost analysis was not evaluated. }\end{array}$ & $\checkmark$ & \\
\hline
\end{tabular}




\section{Appendix P}

\begin{tabular}{|c|c|c|c|c|c|}
\hline Authors & $\begin{array}{l}\text { Procedure/Type } \\
\text { of surgery }\end{array}$ & $\begin{array}{l}\text { Pain Scale } \\
\text { Used }\end{array}$ & $\begin{array}{l}\text { Dosage } \\
\text { Used } \\
\text { (mcg) }\end{array}$ & $\begin{array}{l}\text { Control } \\
\text { Group- } \\
\text { mean time } \\
\text { to first } \\
\text { analgesic } \\
\text { request } \\
\text { (minutes) }\end{array}$ & $\begin{array}{l}\text { Intervention } \\
\text { Group- mean } \\
\text { time to first } \\
\text { analgesic } \\
\text { request } \\
\text { (minutes) }\end{array}$ \\
\hline $\begin{array}{l}\text { Kim et al., } \\
2013\end{array}$ & $\begin{array}{l}\text { Transurethral } \\
\text { prostatectomy }\end{array}$ & VAS & $3 \mathrm{mcg}$ & 345 & 1360 \\
\hline $\begin{array}{l}\text { Abdelhamid } \\
\text { \& El-lakany, } \\
2013\end{array}$ & $\begin{array}{l}\text { Lower } \\
\text { abdominal } \\
\text { surgery }\end{array}$ & $\begin{array}{l}\text { No scale; } \\
\text { results } \\
\text { were } \\
\text { assessed } \\
\text { by } \\
\text { evaluating } \\
\text { time to } \\
\text { analgesic } \\
\text { request }\end{array}$ & $5 \mathrm{mcg}$ & 259 & 381 \\
\hline $\begin{array}{l}\text { Yektaş, A., \& } \\
\text { Belli, E., } \\
2014\end{array}$ & Inguinal surgery & $\begin{array}{l}\text { Numerical } \\
\text { pain rating } \\
\text { scale }\end{array}$ & $\begin{array}{l}2 \mathrm{mcg} \\
\& \\
4 \mathrm{mcg}\end{array}$ & 220 & $\begin{array}{l}\text {-group 2: } 371 \\
\text {-group 3: } \\
1042\end{array}$ \\
\hline $\begin{array}{l}\text { Bi et al., } \\
2017\end{array}$ & Cesarian section & VAS & $\begin{array}{l}3 \mathrm{mcg} \\
\& \\
5 \mathrm{mcg}\end{array}$ & 1320 & $\begin{array}{l}\text {-Bup+Dex3 } \\
\text { Group: } 1488 \\
\text {-Bup+Dex5 } \\
\text { Group: } 1428\end{array}$ \\
\hline $\begin{array}{l}\text { Salem, R.A. } \\
\text { et al., } 2015\end{array}$ & $\begin{array}{l}\text { Posterolateral } \\
\text { lumbar spine } \\
\text { fusion }\end{array}$ & $\begin{array}{l}\text { No scale; } \\
\text { results } \\
\text { were } \\
\text { assessed } \\
\text { by } \\
\text { evaluating } \\
\text { time to } \\
\text { analgesic } \\
\text { request }\end{array}$ & $5 \mathrm{mcg}$ & 269 & 399 \\
\hline $\begin{array}{l}\text { Patro et al., } \\
2016\end{array}$ & $\begin{array}{l}\text { Infra-umbilical } \\
\text { surgeries }\end{array}$ & VAS & $5 \mathrm{mcg}$ & 193.6 & 333.6 \\
\hline
\end{tabular}

